University of Nebraska - Lincoln

DigitalCommons@University of Nebraska - Lincoln

Zea E-Books Collection

Zea E-Books

$12-12-2021$

\title{
I Am a Cat
}

Natsume Sōseki

Follow this and additional works at: https://digitalcommons.unl.edu/zeabook

Part of the Fiction Commons, Japanese Studies Commons, and the Language Interpretation and Translation Commons

\section{Recommended Citation}

Sōseki, Natsume, "I Am a Cat" (2021). Zea E-Books Collection. 112.

https://digitalcommons.unl.edu/zeabook/112

This Book is brought to you for free and open access by the Zea E-Books at DigitalCommons@University of Nebraska - Lincoln. It has been accepted for inclusion in Zea E-Books Collection by an authorized administrator of DigitalCommons@University of Nebraska - Lincoln. 

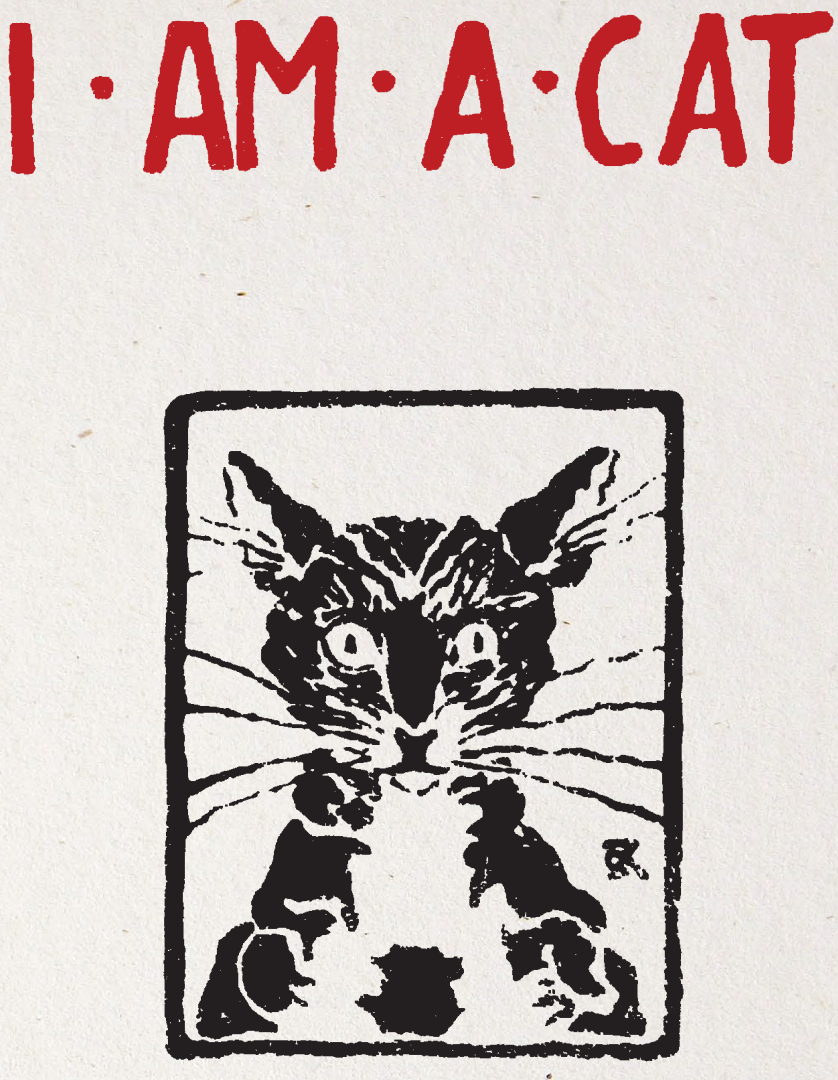

\section{TRANSLATED BY KANDO REVISED BY K-NATSUME}


This English version of 吾輩は猫である（Wagahai-wa neko de aru: I Am a Cat), Chapters I and II, written by Natsume Sōseki, pseudonym of Natsume Kinnosuke (1867-1916), and translated by Kan-ichi Ando (1878-1924), was published by Hattori Shoten, Tokyo, in 1906. The translator writes:

Of all his works, however, the most ingenious one that received its due notice from the public is perhaps his "Wagahai wa Neko de aru" (I am a Cat). It is cleverly written with originality and conviction, and sparks of truth and humor are visible throughout the whole volume. It also reveals the genius with which the writer uses the common daily facts of life in making this excellent bit of literature.... I was so much taken up with this particular work as to desire to see it translated into English. This desire grew so irresistible that at last, yielding to it, I made the following translation, which covers not the whole work which is very copious but only two chapters, intending to work out the remainder by degrees. Far be it from me to make any pretension of having done justice to this admirable story! ... If my readers can get even a glimpse of the charms of the original work, I am more than satisfied. My thanks are due to Miss Hart and Mr. Natsume, the original writer, whose suggestions and revisions have most to do with the making of this little book.

ISBN 978-1-60962-219-0 ebook

doi: $10.32873 /$ unl.dc.zea.1310

Zea Books

Lincoln, Nebraska 


\section{AM A CAI! $\left\{\begin{array}{l}\text { CHAPTER I. } \\ \text { CHAPTER II. }\end{array}\right\}$}

TRANSLATED BY

\section{K. ANDO.}

REVISED BY

\section{K. NATSUME.}

andiches

LINCOLN:

ZEA BOOKS.

2021 
This English version of 吾輩は猫である Wagahai-wa neko de aru (I Am a Cat), Chapters I and II, written by Natsume Sōseki, pseudonym of Natsume Kinnosuke (1867-1916), and translated by Kan-ichi Ando (1878-1924), was published by Hattori Shoten, Tokyo, in 1906.

\section{ISBN 978-1-60962-218-3 paperback ISBN 978-1-60962-219-0 ebook doi: 10.32873/unl.dc.zea.1310 \\ Zea Books are published by the University of Nebraska-Lincoln Libraries.}

Electronic (pdf) edition available online at https://digitalcommons.unl.edu/zeabook/

Print edition available from Lulu.com at http://www.lulu.com/spotlight/unllib

University of Nebraska-Lincoln does not discriminate based upon any protected status. Please go to http://www.unl.edu/equity/notice-nondiscrimination
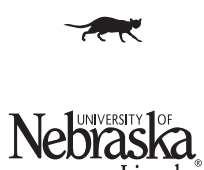

Lincoln 


\section{PREFACE.}

instrenes

Love-stories are all right. But when they are produced in such an enormous mass as at present, they become a nuisance. The more so, when they are slipshod stuff, for the most part, with demoralizing "High-collarists" and "Hisashigami" as their chief characters. Their constructions, which are nearly of a piece, are stale and dull. Their charm, if it may be called so, invariably consists in scandalous incidents and offensive dialogues. These are the productions which, catching the attention of wide circles of youthful readers, have long remained the master of the literary field. But such "going on" are not to last for ever. As we naturally want to smack the lips at some refreshing dishes when always served with the same old insipid meal, so there has been of late in the reading community a reaction demanding new works with an enlivening literary setting. Nor were a number of intelligent writers slow to take up their pens to meet this demand. But none has come out so successfully 
as Mr. Natsume who, so shrewdly grasping the chance, has established himself with one bound among the best writers of the day. And no wonder; his works are of intrinsic literary worth. He writes in a simple natural style, with crisp figures and phraseology, carrying with it a touch of poetic charm. He sometimes writes such romantic tales as "The Tower of London" and Maboroshi-no-tate," etc., and at other times such suggestive stories as "Shumi-noiden," "Koto-no-Karane" and "Botchan" etc.. Of all his works, however, the most ingenious one that received its due notice from the public is perhaps his "Wagahai wa Neko de aru" (I am a Cat). It is cleverly written with originality and conviction, and sparks of truth and humor are visible throughout the whole volume. It also reveals the genius with which the writer uses the common daily facts of life in making this excellent bit of literature. Well it deserves a seventh edition,

I was so much taken up with this particular work as to desire to see it translated into English. This desire grew so irresistible that at last, yielding to it, I made the following translation, which covers not the whole work which is very copious but only two chapters, intending 
to work out the remainder by degrees. Far be it from me to make any pretension of having done justice to this admirable story! Such a task is not an easy one for any professed English scholar, especially the passages in which "Kurumaya's Black" appears with his smart "Edokko" slang. If my readers can get even a glimpse of the charms of the original work, I am more than satisfied. My thanks are due to Miss Hart and Mr. Natsume, the original writer, whose suggestions and revisions have most to do with the making of this little book.

KAN-ICHI ANDO.

Uyeda, August, 1906. 


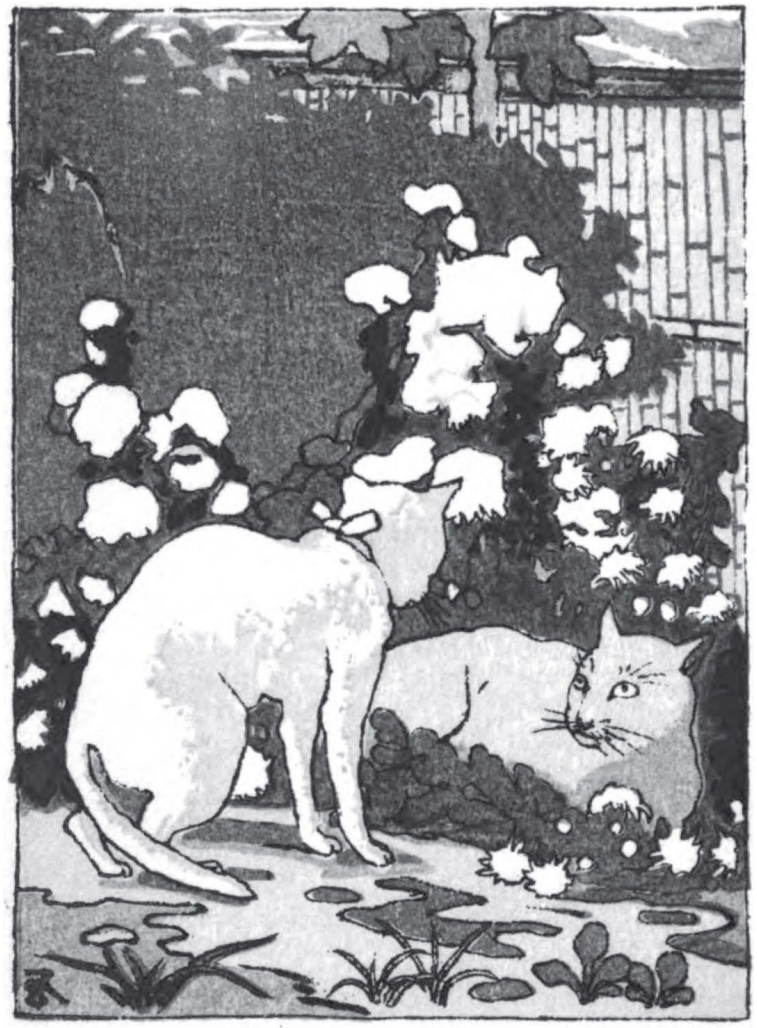




\section{AMACAT}

\section{CHAPTER I.}

TAM a cat; but as yet I have no name.

1 Where I was born is entirely unknown to me. But this still dimly lives in my memory. I was mewing in a gloomy damp place, where I got the first sight of a creature called man. This human being, as I afterwards learned, belonged to the most brutal class of his race, known by the name of "students," who, as it is said, will not unfrequently seize, boil and devour us. But knowing at that time little of what he was like, I felt no fear in particular. Only when he lighted me lightly on his hand, I experienced a strange sensation of buoyancy passing through me. That was all.

It was at this instant that I, collecting myself a little, while thus perched on his palm, cast a glance at his face. This was my first contact with a human creature. I thought then how strange he looked. And I bear this impression to this day. To 
begin with, his face, which ought to have been adorned with hair, was as smooth and slippery as a kettle. I have seen many a cat in my day, but never have I come across one so deformed. Not only that, the face protruded too much in the centre; and from the two cavities of this projection, smoke puffed out now and then, making it hard for me to keep from choking. That this smoke came from tobacco which man uses, did not come to my knowledge until quite recently.

I sat comfortably for a few moments on this student's palm; then I began to feel myself in full motion. Whether he was moving or I alone was being whirled, was more than I could tell. At any rate, I felt fearfully giddy and qualmish, and began to prepare for the worst, when "thud!" came a sound, and sparks flew from my eyes. As to what happened next my memory utterly fails me.

When I came to myself the student had already gone, and not a shadow was to be seen of my brothers and sisters who had been with me en masse. But the worst was the disappearance of my mamma. Besides, instead of being in the shade, I now found myself in a flood of light, — so dazzling that I could scarcely keep my eyes open.

"There is something strange about this, "thought I, and began to creep slowly, when I felt a pricking pain in my paws. Out of the straw that 
received me at my birth, I had been cast away into a thicket of bamboo grass!

I toiled through the thicket as far as a big pond, which I saw in front of me. I sat down by it, and wondered what I had better do. But nothing bright came into my mind. After a while, the thought struck me that if I mewed that student might come again to get me. This experiment, however, was of no avail. In the meantime a smart breath of air rippled the pond, and the sun began to sink. I was feeling very hungry, and fain would cry, but my voice failed me. The only thing I could do was to go somewhere in search of something to eat. Thus resolved, I wormed my way along the left side of the pond. It was indeed a trying expedition. But taking heart I steadily worked on until at last I came to a place where I fancied it smelled of man.

A gap in a bamboo fence caught my eye. Thinking it would help me, I crawled through it into a yard. How strangely the wheel of Fortune turns! Had it not been for this gap, I might have starved to death on the roadside. "Even a rest under the shade of the same tree has something to do with a certain affinity in a previous life." The proverb has much truth in it, for this gap has become the passage by which, to this day, I pay visits to Miss Mikè who lives next door. 
Well, I said I crept into the yard. But I was quite at a loss what to do next. By this time it was growing dark; hunger was staring me in the face. Cold came, and rain began to fall, into the bargain. This drove me towards a lighter and warmer place. I think now that I had then already made my way into a dwelling house. Here I had a chance to see other human beings.

The first one was a maid, whom I found to be a more violent creature than the student mentioned before. For, no sooner did she catch sight of me, than she seized me by the neck, and flung me into the yard. Before this formidable foe struggling was useless. So I shut my eye, and gave myself up to Providence. To this brutal treatment were added the pangs of starvation. So I watched another chance, and stole into the kitchen only to be hurled out again. I remember that the same thing was repeated four or five times at least, which deeply impressed me with the feeling that a maid is a very disgusting brute. The other day, by way of tit for tat, I secretly devoured a mackerel pike that was on her plate, and thus relieved my feelings to a certain extent.

When I was about to be thrown out for the last time, a voice came, saying: "What's all this row about, eh?" And the master of this house appeared. "This homeless cat tries my patience," responded 
the maid. "It insists upon coming into the kitchen, do what I will." She showed me to him, snatching me up by the neck. And he, looking at my face, while twirling the black hair above his upper lip, at last said: "Keep it, then," and walked into a back room. He seemed a close-tongued man. The maid dashed me fretfully on to the kitchen floor. It was in this way that I came to settle in this house.

It is rarely that I meet my master in the house. They say he is a teacher by profession. When he comes back from school, he usually shuts himself up in his study for the remainder of the day. The members of his family think him a very diligent scholar; and he himself is trying to appear as such. But in reality he is not so hard at work as his folk say. I often make a stealthy approach to his "den", peep in, and not unfrequently find him taking a nap. Sometimes I even catch him in a ludicrous state, letting water drop from his mouth on to the book he has been reading. He suffers from indigestion, and his sallow complexion tells of the want of elasticity and vitality of his skin. Nevertheless, he is a gormandizer. He eats his fill, takes a drug of "Taka Diastase," opens a book, and reads two or three lines. Then "his eyes begin to draw straws, " and spittle drops upon the book. This is his routine of every night. Though I am a cat, I often think that the lot of a teacher is a very easy 
one, and that it would be well for every creature that is born a man, to enter upon the profession. For, if one who thus dozes away his time, passes as teacher, it cannot be altogether impossible for a cat to be one. Yet, in the opinion of my master, nothing seems harder than to teach. In fact, he makes a business of complaining of his work whenever a friend calls.

At the time when I was first received into this house, I was far from being a pet of any member of the family, save the master. Go where I would, I was kept at arm's length. How badly I have been slighted is known by the fact that to this day they have not even named me. In this sorry plight, I had no choice but to keep as close as possible to the master who had given me permission to stay. I made it a rule to get on his lap when I saw him reading a paper in the morning, and to crawl upon his back when he was taking a siesta. This was not exactly because I liked him, but because I could not help it, there being no one else who cared for me. After many experiences, however, I have come to choose lying on a rice-tub in the morning, on a Kotatsu at night, and in the daytime, when the day is fine, on the veranda. But the most comfortable bed I ever have is when I creep in and sleep with the children in their bed. There are two girls in the household, the one aged five, 
and the other, three. They sleep in the same bed at night made in one of the rooms. I usually find room between, and manage somehow or other to force my way in. But if by ill chance one of the kids awake, I am certain to get into a scrape. Theythe younger is especially churlish,-will cry out no matter how late it is, "The cat is here! The cat is here!" Then my master, who is nervous through indigestion, is sure to open his eyes and come flying from the next room. In fact, the other night I received a severe blow on the back from a measuring-stick he had in his hand.

Since coming to live with human beings, the more I observe them, the more I am led to conclude that they are very selfish. But of all the human creatures with whom I have come into contact, there are none so selfish as the children into whose bed I now and again creep. They often amuse themselves by holding me by the tail, covering my head with a bag, throwing me about, or thrusting me into the oven. And if I dare make the slightest resistance, the whole household runs after me to punish me. The other day when I sharpened my claws a little on a padded mat, the mistress got so angry that she has rarely let me into the living-rooms since. And they do not "care a straw for me" even if they see me shivering with the cold on the kitchen floor. 
Mrs. White, my opposite neighbor, whom I hold in high esteem, also gives expression to the same sentiment whenever I meet her, saying that there hardly exists any creature less capable of compassion than man. Sometime ago, she gave birth to four lovely kittens. What has become of them? Three days later they were seized by the fiendish student of her house, and cast away, all of them, into a pond behind the house. Mrs. White, with tears in her eyes, told me this sad fact; and added that unless we wage war against the human race, and succeed in destroying it to the last man, we, cats, can never make sweet peaceful homes to safeguard true domestic affection, - an opinion full of sense and truth.

Again, Miss Mikè, my next door neighbor, is very indignant that man has not a perfect conception of ownership. It is, among our cat society, an established usage that the first discoverer of any food, whether it be a head of dried sardine or a slice of mullet, is entitled to eat it. In case anyone should defy this time honored custom, we may go so far as to wrench our prize away from him by force. But man seemingly fails to take in this idea. As it is, he always robs us of the dainties we have found. Using his force, he remorselessly snatches from us that to which we lay just claim. Mrs. White lives in a soldier's household, 
and Miss Mikè in a barrister's. But living with an easy-going teacher, I hold rather an optimistic view with regard to such matters. I am satisfied if I can only manage to procure my daily food. Mighty as man is, he will not always be "lord of creation." In the meanwhile, let us patiently wait for the day when we shall have it all our own way.

Talking of selfishness reminds me of my master who went astray through this very weakness. He has no special attainment to recommend him above any other person. But he wishes to try his hand at everything. Now he makes a kind of verse called "Haiku," which he contributes to the Hototogisu; again, he writes another kind of poem known as "Shintaishi," and puts it in the Myojo. He sometimes writes an English composition full of blunders. Then he is taken up with archery; and then he learns to sing an operatic song named "Utai." Then his whim is to scrape noisily on a fiddle. But in any of these things, I am sorry to say, he never does well. Nevertheless, he stubbornly sticks to each of them at the start, though suffering from indigestion. He is nicknamed. "Professor Privy" by the neighbors, for he often sings "Utai" in a backhouse. Still he keeps to repeat unconcernedly, "Of the Taira clan I am, known by the name of Munemori." Here he begins 'Munemori,' say the neighbors, bursting out laughing. 
I do not know what put it into his head; but one day - it was on the day he usually receives his salary-after I had been with him a month, my master came home in great haste with a big parcel in his hand. I wondered what he had bought; but I soon found that they were a box of pigments for water coloring, some brushes, and some sheets of paper called "Watman's." It seemed his intention to give up "Utai" and "Hai-ku" from that day for painting. I was right. For some time he was daily seen in his study engrossed in using his brushes, entirely forgetting to take his customary nap. But the pictures he worked out were such that no one could tell what they represented. The painter himself seemed to think he was not up to the mark; for, one day when one of his friends who is studying - esthetics, if I remember rightly, called on him, I heard the following conversation.

"It's really very hard to be a good artist," confessed my master. "When we see the productions of others, we fancy they may be easily done. But we never realize the difficulties until we actually take up a brush ourselves." And this was what he really thought.

"You can hardly expect to be perfect from the outset," responded the guest, glancing at my master over his gold-rimmed glasses. Besides, it is of no use to shut yourself up and try to paint from 
mere imagination. Andrea del Sarto, an old Italian artist of note, once said:- 'An artist should sketch nature itself. Stars twinkle in the sky. Dew spangles the earth with its watery pearls. Here, fowls of the air are floating at their ease; there, beasts of the field are roaming in peace. Here is a crow perched on a dead leafless branch, its black plumage contrasting with the yellow scales of the gold fish that swim leisurely in the pond below. In a word, nature is a big stretch of living pictures.' What do you say," added the esthete, "if you study painting at all, to take to sketching nature, as this great artist urges?"

"Did Andrea del Sarto give such a valuable suggestion? I have never heard of it before. He is quite right. Yes, every word he says is true." My master was lost in admiration, while the other eyed him, as I thought, from the corner of his glasses with a sort of derisive smile.

The next day when I was comfortably napping as usual on the veranda, my master-strange to say - was found out of his study, busily occupied in some work behind my back. I chanced to awake; and wondering what he was doing, cast a side-long glance with my eyes partially opened, and perceived him intent upon imitating Andrea del Sarto. The sight was so amusing that I could hardly keep from laughing. As you know, 
the esthetician was making a hare of him, but he took it in earnest, with the result that he made me the first object of his sketching. I had slept sufficiently, and wanted to yawn very much, but I kept forbearing it with effort, for I felt sorry to disturb him by moving; he was working so earnestly. He had just completed my outlines, and was now coloring about the face.

Now, I confess that I, as a cat, am not handsome. And so I never presume that I am in any respect more attractive than any other cat, either as to my features, the form of my back, or the color of my hair. But however homely I may look, I could not for a moment believe I was like that strange animal outlined by my master. In the first place, the color of hair was different. My hair is, not unlike that of a cat of Persian birth, tinted with a yellowish-grey with jet-black spots. This at least is, I think, a self-evident fact. But the color he used was neither yellow, black, grey, nor brown. Nor was it a mixture of all these. I do not know how to express it, excepting to say that it was a sort of color. Added to this was the fact that the animal had no eyes. True, it was excusable to a certain extent since he sketched me while sleeping. But then even an indication of eyes should have been seen. As it was, nobody could tell whether it was a blind cat or a sleeping one. In the face of this 
gross daub, I secretly concluded that the wouldbe pupil of Andrea del Sarto would never make a good artist. But at the same time I could not but admire his zeal. I meant to oblige him, if possible, by remaining motionless; but unfortunately I could endure it no longer. I got up abruptly, stretched my paws fully, lengthened my neck low, and yawned heartily. Now that I once moved, it was of no use remaining still; my master's plan was upset after all. So I began to creep off slowly towards the back door. "You blockhead!" my master cried behind me in a tone of voice mingled with anger and despair. This abusive language is invariably used by him when he is angry with others. He does not know of any other way of calling names. Still it was unpardonable to insult me in this way, with no feeling of gratitude for the patience with which I had served as a model. However I would not have minded it, had he proved more obliging when I wished to sit on his back now and again. He has never willingly granted me any favor. And now he dared call me a blockhead for leaving the veranda. This was more than I could bear. The socalled human beings, one and all, conduct themselves with the most arrogant audacity, taking undue pride on their superior strength. There is no knowing how far they will carry on their arrogance, if some stronger creatures do not appear in 
the world to suppress them. Such an instance of selfishness, however, may be leniently regarded. I have been informed of a much more lamentable proof of human wickedness.

There is a small tea-garden at the back of my house, about ten tsubo in area. Though not wide, it is a nice clean place, and is comfortably lighted by the sun. It is my favorite resort when I cannot indulge in a nap at home on account of the deafening noise made by the children, or when I am not well. One mild autumn day, about two o'clock in the afternoon, after having had lunch and a comfortable sleep, I betook myself there for a stroll. Sniffing the roots of tea-plants, one after the other, I came as far as the hedge on the western side, where I found a big cat in a deep sleep on the withered chrysanthemums pressed down under his weight. He lay snoring loudly, measuring his length as if quite unconscious of my approach, or if conscious, as if pretending to take no notice of me. Think of anyone thus making himself at home in another man's yard! I could not help admiring the stranger's boldness. He was jet-black from head to foot. It was a little past noon, and the bright sun threw its transparent rays upon his glossy fur coat, making it shine as if emitting some invisible flame. His physical constitution, too, was so splendid that we might offer him the title of King of Cats. I may 
safely say that he was twice as large as I. I stood like a statue gazing at this noble creature, lost in mingled feelings of admiration and curiosity.

Just then a gentle puff of autumn wind lightly waved the branches of the kiri above the hedge, and sent two or three leaves fluttering down on a bunch of withered chrysanthemums. Black King flashed open his round eyes, which shone far more beautifully, as I remember to this day, than the socalled amber much valued by man. Without in the least moving his body, he rested a fiery glare upon me, and demanded: "What the deuce are you?"

I thought his language was a little too rude for King; but then there was in his tone of voice something imperial which might cow even a dog. I was not a little frightened. Not to make any answer, however, was dangerous, I thought. "I am a cat; but I have no name yet," I replied in a cold tone, assuming an air as calm as possible. But I confess that my heart throbbed harder than usual.

"Cat? Hang it! Where are you vegitating?" said he, curling up his lip as proud as Lucifer.

"I live in this teacher's house."

"I am not a bit surprised to hear it. No wonder you are as thin as a wafer!" bragged Black King, with looks befitting a King.

Conjecturing from his manner of speaking, I could not but infer that he was anything but a 
well-bred cat. But at the same time it must be allowed, considering he was so fat and plump, that he was well fed, in other words, he "lived in clover."

"And who on earth are you?" I inquired, prompted by curiosity.

"I am Black of the rikisha man's house," was the proud answer.

Now, Black of the jinrikisha man's house is notorious in the neighborhood for the wild unruly manner with which he carries himself. "Like master, like man." He is only very strong, with no education at all. For this reason, few cats go into his society, all agreeing to keep him at a respectful distance. As is imagined, his name inspired in me some fear on one hand; but also roused contempt on the other. I wanted to test first of all how little he knew, and so carried on a conversation thus:-

"Which is greater, a teacher or a rikisha man?"

"It goes without saying that the latter is stronger. Look at your master. He is mere skin and bone."

"Like your master you look very strong. I presume you feed on good food."

Pshaw! For my part, I believe I shall never be in want of food wherever I may go. It would be well for you to turn away from your idle rambling round the tea-garden, and follow at my heels a 
little. And then you'll grow marvellously fat ere a month passes away."

"Thanks! I'll do so by and by. By the way the teacher lives, I think, in a larger house than the rikisha man."

"Bah! Simpleton you are to think a big house brings a full stomach!"

He appeared to be very much offended; for he rose up and went away rudely, convulsively moving his ears which bore some resemblance to a piece of bamboo obliquely chipped.

It was in this way that I became acquainted with Black of the jinrikisha man's house.

I have often fallen in with him since then. And everytime I meet with him, he talks big after a fashion becoming his social position. The case of human scandal, which I referred to before, was in fact related to me by Black.

One day Black and I were lying as usual in the sunny tea-garden desultorily talking. After going over his habitual boasting as if it always sounded novel, he popped a question:-

"How many rats have you caught?" Now I believe that in the development of intellectual powers I have quite the upper-hand of him: in point of strength and courage, however, I must admit that he is more than my match. In the face of this question, therefore, I could not but feel very small. But a fact is a fact; it cannot be lied. 
"I have always had a great desire to catch them," I confessed, "but I have not yet realized my wish."

At this Black laughed a hearty laugh, quivering the long whiskers sticking out from the sides of his mouth. As is ordinary with boasters, he has some apartments to let. If I only pretend to listen to his self-commendation by purring as if in admiration, he is an easy customer to deal with. I shrewdly learned this way of handling him almost as soon as I got acquainted with him.

Under the circumstance, therefore, I thought it unwise to attempt an explanation and perhaps make matters worse. Far better to let him mount his high horse again and thus to give him the slip. Thus determined, I said in a gentle subdued tone of voice:-

"You have lived long in the world, and I have no doubt you have caught a lot of the animals."

This had the desired effect; for he swallowed the bait easily.

"Not very many. Between thirty and forty, if I remember rightly," he answered pleased as Punch. "I can at any time take solely upon myself to catch one or two hundred rats," he went on, "but the most cunning wretch is a weasel, as I once found by experience."

"Oh, indeed!" I chimed in. 
"It was one day last year," continued my friend, snapping his big eyes, "when we house-cleaned, that a big weasel jumped out helter-skelter from under the floor taken by surprise by my master who crept under with a bag of lime."

"Hum!" I inserted, feigning amazement.

"You may take a weasel for a big animal; but in reality he is only slightly larger than a rat. 'I'll catch him,' thought I, and gave chase, succeeding at last in driving him into a drain."

Hurrah for your success!" I cried ostentatiously in applause.

"But listen! When I was about to have him in my power, he emitted, by way of final defence, a very disagreeable gas. How offensively it smelt may be known by the fact that I, to this day, feel sick whenever I catch sight of the animal." Here he raised one of his paws and rubbed the tip of his nose two or three times as though he smelt the dreadful odor. I felt a little sorry for him, and thought of encouraging him a bit.

"But so far as rats are concerned, I presume that they are undone when once under your fatal glance. No doubt you are much of a ratter and feast luxuriously on them. That accounts for your stout muscles and glossy coat; doesn't it?" The question which was intended to please him, strangely brought about a contrary issue. 
"The thought of it makes me tired," he said, with a heavy sigh of dejection. Strive as I may to catch rats ...... There hardly lives in the whole world a more shameless brute than man. He seizes upon the rats we catch, and takes them to a police-box. Not knowing who has caught them, policemen give five sen per head to anyone who brings them. The master of my house, for instance, has already pocketed one yen and fifty sen at my expense. And yet he gives me nothing good to eat. I declare that man, in plain terms, a wolf in sheep's clothing." Uneducated as he was, he seemed to have sense enough to see through such a question. His hair stood erect, and he was evidently flushed with anger against human injustice. Having become a little fearful, I managed artfully to slip away from him, and got home.

From that time I made up my mind never to catch a rat. Nor have I stooped to become a follower of Black in order to hunt after nice food other than rats. I content myself with having a sleep in a snug corner rather than supping on a rich meal. Even a cat, if he lives with a teacher, seems to take after his disposition. If I do not take care of myself, I shall probably become a dyspeptic myself. Talking of a teacher, my master seemed to see that he would never make a good painter; for on the first of December he recorded in his diary as follows:- 
"Made acquaintance with A... at to-day's meeting. They say he was once dissipated; could see that plainly by his easy manners. This sort of man is generally liked by the opposite sex. May be, he was tempted to sow his wild oats, simply because he was invited to sow them. His wife is said to be a geisha: what a Bohemian! Most of those who attack sensualists are those who would like to be in the same place themselves. And of a class of men acknowledging themselves as such, few have the true epicurean taste. They plunge into dissipation, without the least idea of deriving any benefit out of it. I wager they will never come off well, just as I shall not in water-coloring. Notwithstanding this they take delight in assuming the petty airs of knowing ones. If the mere practice of drinking at a restaurant or haunting machi-ai could make a beau, there is no reason why I could not be a good water-colorist. Such a dauber as I had better not daub at all. For the same reason, it is far better to be a greenhorn than a stupid dude."

I cannot easily agree with this opinion of his. As to his envious reference to another man's having a geisha as wife, it was a great shame for a teacher to give utterance to such an idea. I admit, however, that his critical judgment of his own ability for water-coloring was quite right. But with this self-knowledge, he is still not free from 
vanity. Two days after, on the fourth of December, he made the following entry in his diary:-

"Dreamed last night that somebody had hung on the wall, in a fine frame, one of my pictures, which I had laid aside as a poor piece of work. Thus set up in a frame, it seemed suddenly transformed, much to my delight, to a beautiful picture. I kept looking at it with admiration until the dawn of day, when I awoke to find in it the former daub as clearly as the rising sun which fell upon it."

He seems to carry his water colours on his back even into the realm of his dreams. As things stand, it is not possible for him to form an idea as to what an arbiter elegantiarum is, not to say anything of becoming an artist. The day after he had that dream of water-coloring, the esthetician with gold-rimmed glasses on who had not come for a long time, turned in to see my master.

"How are you getting on with your water-coloring?" were the first words the visitor uttered on being seated.

"Following your counsel, I am devoting my self to sketching," replied my master with a calm air. "By the practice of sketching, as you rightly remarked, we come to take in the various forms of objects which otherwise escape our attention, as well as the delicate shades of colors. The present 
progress in painting in Western lands has undoubtedly much to do with the unfailing application with which the artists have held on to sketching for ages. And Andrea del Sarto among the rest claims our special attention." Not breathing a word of what he had noted in his diary, my master again sang praises to Andrea del Sarto.

"To be frank, I spoke it at random," laughed the esthetician, scratching his head.

"What do you mean?" returned my master who was still not aware of his having been made game of.

"Why, I mean no other than that Andrea del Sarto affair you admire so much. It was brewed somewhere in the dim region of my imagination; nothing more. And I never thought that you would take it in sober-earnestness. Ha! ha! ha!" confessed the visitor with a self-flattering manner.

I overheard this dialogue on the veranda, and could not but wonder what entry would be made in the poor teacher's diary that day. This esthetician makes it his sole enjoyment to play tricks upon other people by means of such make-believes. As if quite unconcerned that his Andrea del Sarto had touched a chord of my master's heart, the trickster continued triumphantly:-

"It is amusing to think that my facetious fancy is tickled by the credulity with which 
people receive my occasional jokes. The other day I told a certain student in joke that Nicholas Nicholbey suggested to Gibbon the idea of giving up his plan of writing in French one of his greatest works, "The French Revolution," and that was why it came out in English. He was a man of remarkable memory; and it was funny to hear him seriously repeat in his speech at a meeting of Japanese Literary Society exactly what I had told him. All those present numbering some one hundred, in turn, listened to him in good earnest. I have a still more amusing story. Sometime ago, while in company with a certain man-of-letters, our conversation turned to Theophano, an historical romance by Frederic Harrison. I declared it a model historical novel, remarking that the chapters leading to the death of the heroine are especially thrilling. Then a man sitting in front of me, who never says "I don't know" in any matter, chimed in with 'Yes, yes, the passages you refer to are capital compositions.' I understood by this remark that he, like myself, had not read the romance."

My master, who is nervous through dyspepsia, opened his eyes in amazement, and questioned: "And what would you do after making such a statement, supposing the man had actually perused that novel?" 
By this question it seemed that he thought there is no objection to deceiving other people, the only difficulty being the danger of being caught in his own trick.

"Why, I should have said then that I took it for another book, or some such things," said Mr. Meitei, cackling. This esthetician, though wearing gold-rimmed glasses, bears some resemblance in his temperament to Kurumaya's Black.

My master silently smoked Hinodiè in whiffs, with an expression of disapproval. The visitor eyed him as much as to say that it was this very want of tact that made my master a failure as an artist, and said: "But joking aside, it is really very hard to paint well. Leonardo da Vinci is said to have once advised his pupils to sketch the stains on the walls of a cathedral. His words also hold good even to a rain-stained wall of a back-house; for from close observation of such stains one is apt to derive excellent specimens of pictorial designs. Try such a sketch with proper care, and you are sure to get a good piece of work."

"I see you are playing another trick on me."

"No, you may rely upon me this time. You see this is so suggestive and is just what Vinci would say."

"Yes, it is certainly suggestive," said my master, half yielding. But he has not yet actually sketched in the privy. 
Kurumaya's Black has since become crippled. His glossy fur has begun to fade and grow thin. And his eyes, once brighter than amber, as I said before, have lost their brilliancy and seem very sore. But above all, what attracted my attention most was the decline of his spirits and physical constitution. When I saw him last in the garden and enquired after his health, he said: "I have never had such hard lessons as those from a weasel and a fishmonger's tem-bimbo.*

The leaves of the maples which spread betwixt the Akamatsu $\dagger$ a rich drapery of crimson hue, have faded away like a dream. Camellias have ceased to shower their red and white petals near the wash-stand outside the tea-room. The winter sun declines earlier on the south-facing veranda. We have scarcely a day which is not windy. And I feel as if the hours of my nap have been shortened.

My master goes to school every day. Upon his return he confines himself to his study. When his friends come, he complains of the lot of a teacher. He rarely sits of late for water coloring. He has ceased to take Taka-Diastase, saying it does him

* The pole used for carrying burdens across the shoulder.

$\dagger$ Literally a red pine-tree; so called from its reddish stem and branches. 
little good. Much to their credit, the kids regularly go to a kinder-garten. When they come back, they sing nursery rhymes, play temari, $\ddagger$ and now and then hang me by the tail.

Not feeding on rich food, I have not grown fat in particular. But I am living in comparatively good health-for which I am thankful, not sharing the fate of Black. I never catch any rats. I dislike the maid-servant as much as ever. I am not named yet. But there is no end to one's desires, so I mean to live and die a nameless cat in this teacher's house.

$\ddagger$ A popular game among Japanese girls of striking a small ball with the hand. 


\section{CHAPTER II.}

SINCE the New Year I have gained some fame. $\checkmark$ And it is a source of satisfaction to think that I, though a cat, can hold my head high in some degree.

With the dawn of the New Year's day, my master received a picture card of greeting from one of his friends, a painter. The upper and the lower parts of the card were respectively painted with red and deep green, with a crouching animal in pastel in the centre. My master scanned the picture sideways and lengthways in his study, and said to himself, Splendid color!" Now that he had admired it, I thought he would lay it down. But no! He still went on examining it sideways, lengthways, twisting his body, stretching out his hand in the manner of an old man reading the book called "Sanzeso,"* or turning himself towards the window and bringing it as near as the tip of his nose. I wished that he would put an end to this examination as soon as possible; for his lap shook

* A famous book on horoscopy, by which one's condition in a previous state of existence as well as in the present and future is ascertained. 
to threaten my fall. When at last this agitation subsided in a measure, I heard a low voice from my master, saying, "I wonder what it represents!"

Though impressed with the colors of the card, he seemed to have taken pains in vain to make out the identity of the creature in the centre. Wondering if it was really so strange an animal, I gracefully half opened my eyes, and calmly looked at the picture. It was my likeness. Yes, there was no doubt of it. It was not likely that the picture was painted after the fashion of Andrea del Sarto, as my master once did. But at any rate, I could tell, by the perfect outlines and coloring, that it was by the hand of one who makes painting one's profession. Anyone could tell that it was a cat, and anyone of even a little sense of perception could clearly distinguish in it myself of all cats; it was so unequivocally represented. Still he troubled himself so greatly with this small affair that I felt some pity for human helplessness. I wished to tell him, if possible, that it was my picture, and even if he could not take that in, to make him understand at least that it was a picture of a cat. But man after all is not blessed with such heavenly gifts as to understand the cat's speech. So I was obliged to leave the matter as it was,

I wish to call the attention of my readers to the fact that man has fallen into a habit of 
pooh-poohing us. But it will not do for him to always look down upon us in his proud way. It is not rare among such a class of men as teachers who, being blind to their own ignorance, are puffed up with self-importance, to think the ox and the horse are made from the scum of man and the cat in turn is made from the refuse of the ox and the horse. Fie upon it! Even the cat is not brought into existence so easily. We may look as much alike as if cast in the same mould, each with no individuality of his own. But a close observer of our race can see that we are of all sorts and kinds. In fact, a human saying, "ten men have as many personalities," is equally applicable to the members of our family. For instance, the look of our eye and nose as well as the type of fur and paws are all different. Nor is there any sameness with regard to the style of beards, the form of ears, and the manner in which we hold our tails. Again, there are handsome cats, ugly cats, stylish cats, and rude cats, cats with this taste, and cats with that taste. I am not stretching a bit when I say that the diversity of the natures and features of cats is almost endless. Notwithstanding this marked display of difference, man is unable to make even a slight distinction between the features of one cat and those of another, not to say anything of our nature; because his eyes are lifted to the sky, saying "We 
must always aim at something lofty, etc.." "Birds of a feather flock together." As the old proverb has it, one is the best judge of one's company. So I say that the cat knows better than anyone else about things relating to the cat. Whatever development man may make, he can not be expected to outdo us so far as this question is concerned. The more so when he is not in reality so knowing a creature - not a bit of it! —although he believes himself to be so.

This is particularly the case with my master, who, wanting in sympathy, does not know even the simple truth that "mutual understanding is the first requisite of love." As an obstinate oyster sticks to a rock, so he always keeps close to his study and never pays any attention to the "goings on" in the outside world. And it is ludicrous to see him assume the airs of a man of insight. That he is not one is proved by the fact that even in the actual presence of my likeness there was no indication at all of his having recognized me in it. All he said to himself was this nonsense: "As it is the second year of the Japan-Russia War, this picture perhaps represents the 'Bear."

I was thus thinking, while lying on my master's lap, when the maid brought to him a second picture card. It was a printed one showing a row of some foreign cats engaged in studying, some 
holding pens, and some opening books. Apart from the rest, there was, at a corner of the table, a cat who was dancing a dance of an Occidental cat. Over this cat was written in jet-black Japanese characters, "I am a cat," while on the right side was added a Haiku, which read:

"The spring one long happy day

Of reading and dancing to cats they say."

This card was sent in by one of my master's old pupils, and anyone could see at a glance what it meant. But the thick-skulled master evidently failed to take in this obvious significance.

He shook his head in wonder, and murmured to himself, "Hem! May be, this year is that of the cat: I only wonder whether the cat is one of the twelve calendar signs of the Zodiac. He was apparently still unaware that I had become famous.

Just then the maid brought in a third card. Not a pictured one this time. It was a common post card, on which was written, "I wish you a Happy New Year," and postscripted "Kindly oblige me by remembering me to your cat." The expressions were so unequivocal that even the blunt-witted master seemed to find it easy to grasp the idea. "Hum!" he said at last with a look of recognition, and looked into my face. I thought there was an unusual expression of respect in his eyes. Considering 
it was all through me that an unknown teacher had gained some fame all of a sudden, I think it was only fair to expect such a glance from him.

Just then a bell attached to the gate-door was rung probably by a visitor. Now, visitors are usually shown in by the maid. And I make it a rule not to go to the door to meet anyone, excepting when Ume-kô, a fishmonger, comes. As it was, I sat still on my master's knee, assuming an unconcerned air. But he cast an uneasy glance towards the door as he would have done had a Shylock intruded. He was evidently loath to receive a guest who came to offer him greetings of the New Year, and to keep his company over sakè. He will take the prize for eccentricity. If he really disliked visitors, he ought to have gone out early; but he had not the courage to do that. By this his "oyster-like" character is fully manifested.

Soon the maid appeared announcing the call of "Mr. Kangetsu." A man named Kangetsu is said to be also an old pupil of my master's. But after graduation he got a good position, and they say he is now doing better than his old master. He often comes to see him, though I do not know for what. Whenever he calls, he talks as if there is a girl who loves him or there is not, and as if he enjoys life or he does not. And when he goes over this strange discourse which may be taken either 
as bright or gloomy, he takes his leave. I can hardly understand why he chooses such a seedy man as my master to talk on such matters. And it is amusing to hear this "oyster-like" master chime in now and then with his opinion.

"I beg your pardon for not calling on you sooner. To tell the truth, I have been on the move since the end of last year. But my legs would not carry me in this direction, do what I would," said Mr. Kangetsu ambiguously, playing with the strings of his haori.

"In what direction do you bend your steps?" asked my master, with a serious look, pulling the end of the sleeves of his black montsuki haori.* This haori is of cotton, and is so short in the sleeves that his worn-out silk kimono sticks out two inches.

"To a rather unbeaten track. Ha! ha! ha! laughed Mr. Kangetsu.

I noticed that one of his front teeth had been broken. "What have you done with one of your teeth?" asked my master, by way of changing the topic.

"The fact is I ate some mushrooms at a certain place."

"Ate what?"

"Mushrooms. I tried to bite off the head of a

* An outer coat with family crests. 
mushroom with my front teeth, when one of them broke off with a crack."

"To break off a tooth by eating a mushroom is more proper for a gaffer. It may make a Haiku, but would never do for a love episode," said my master, patting my head.

"Ah, is that the cat you talked of the other day? It's very fat. I say it will not give way even before Kurumaya's Black. It's a splendid cat." Mr. Kangetsu spoke of me in glowing terms.

"It's grown very big of late, you know," said my master with a look of pride, and rapped my head successively. I was quite satisfied with the praise; but I confess his taps gave me some pain."

"The night before last," said Mr. Kangetsu, resuming the original topic, "we held another little concert."

"Where?"

"You need not be anxious to know the place. We had a glorious time with a concert of three violins and a piano. Now even a poor performance on violins is sweet enough to please the ear, if played together by three or four persons. Well, two of the players were ladies, and I joined them. And I flatter myself that I played unusually well."

"Hum! And who were the ladies?" questioned my master, in an envious tone. 
Although his personal appearance is "as impassive as the marble in the quarry," my master is by no means classed among those who pay little attention to the softer sex. He once read a foreign novel in which a character is satirically described as invariably sweet upon woman in general, and falls in love with $70 \%$ of the women he sees. When he came to that chapter, he was much moved by the description, and declared it true. This proves what sort of a man he is. Then why does such a fickle man keep so close to his shell? It is a hard nut for me to crack. Some say it is owing to his lost love, some, to his weak stomach, while others ascribe it to his meagre means and timidity. At any rate, it is not worth while to make any inquiry into the cause, since he is the man least likely to be recorded in the history of the Meiji Era. Let me simply say that at least the fact of his envious inquiry after Mr. Kangetsu's lady-friends admits of no doubt.

Mr. Kangetsu picked humorously with his chop-sticks a piece of Kama-bokô ${ }^{*}$ on a side dish, and bit it in two with his front teeth. I feared he would lose another tooth. But there was no danger of it this time.

* Flesh of fish hashed, rolled around a stick and baked. 
"Why, both the ladies," he replied coldly, "are the daughters of certain gentlemen. You have no personal acquaintance with them."

"Oh," drawled my master. But without finishing the next word, "indeed," he plunged into thought.

"I should like to accompany you for a stroll, if you are not otherwise engaged," invited Mr. Kangetsu, who seemed to think that he had sufficiently vexed his host. "The weather is very fine. And the news of the fall of Port Arthur has thrown the whole capital into stir and life."

But my master was still absorbed in meditation, with looks as much as to say that an explanation of the ladies was of more importance to him than the fall of the stronghold. After a time, however, he seemed to give up the inquiry for a walk.

"Let us go out, then," he said and stood up determinedly.

He was dressed in the same old clothes,- the crested black haori of cotton cloth, and a wornout winter garment given, as is said, by his brother as a keepsake, which had been in use for twenty years. It was of a strong stuff called Yuki-tsumugi. But however durable the stuff might be, it could not last for ever. As it was, the costume was frayed so badly here and there that, when held up to the light, one could see the stitches of patches inside. 
He wears the same clothes year in and year out. His everyday clothes are worn for all special occasions. As may be imagined, he does not trouble himself with changing his clothes when he goes out. He simply leaves home with his hands in his bosom. I do not know whether or not he has any holiday garments, but, even if he has any, he saves himself the trouble of changing his ordinary clothes for them. I am prone to think, however, that this habit at least has nothing to do with his supposed lost love.

After my master and Mr. Kangetsu had gone cut, I took the liberty to help myself to the remnant of Kama-bokô bitten off by the guest. You know I am no common cat of late. I believe I am not presumptuous when I say that I am as worthy of notice as the cat whose story used to be a favorite one of Momokawa Joen, a famous raconteur, or the cat who stole Gray's goldfish. It is taken for granted that I take no account of such a fellow as Kurumaya's Black. So I think I am not to be blamed for such a trifle as freely eating a slice or two of Kama-bokô. Besides, the habit of eating on the sly between meals is not necessarily peculiar to our race alone. The maid of our house, for instance, often makes herself quite at home when the mistress is out, and helps herself freely to sweets. Nor is the maid the only exception. 
Even the children who are declared by the mistress as being taught manners, are not free from this inclination.

A few days ago, both the kids got up awfully early, and while their parents were still in bed, they sat at table facing each other. They are used to getting a portion of the bread which forms my master's breakfast, and to eat it with sugar. On this morning they happened to find a sugar jar on the table, with a spoon invitingly laid beside it. Finding no one to help them to their usual share of sugar, the elder girl took a spoonful out of the jar, and put it on her plate. Then the younger one got a similar quantity on her plate by the same means. For a time they stared at each other. Then the elder took hold of the spoon, and added another spoonful to her plate. The younger soon followed this example, making her share equal. Then the elder got another spoonful. The younger soon did the same. Then the one laid her hand on the jar, while the other took hold of the spoon. In this way, the plate of each went on receiving spoonful after spoonful, until it soon made an overflowing heap of sugar. The jar was thus almost emptied, when my master came out of the bedchamber, rubbing his sleepy eyes: and the jar was soon filled with its original contents. One can easily surmise from this that although in point of the 
idea of fairness originating from egoism, man may be surpassed, he is not fit to hold a candle to us as regards wit. I thought it would be well for the children to at once enjoy a free taste of sugar, before they made such heaps. But as they could not, as I said before, understand my speech, I could not but sit silently on a rice-tub and observe their stupid proceedings.

I do not know where my master really went with Mr. Kangetsu. But he returned home very late that night. It was about nine o'clock next morning that the family sat at breakfast. I took my usual seat on the rice-tub, and surveyed them. My master was silently gulping zoni. ${ }^{*}$ He emptied bowl after bowl. True, the mochi $\dagger^{*}$ was in small pieces; but then he devoured, I remember, six or seven pieces. Leaving the last piece in his bowl, he finally laid down his busy chop-sticks, and said: "Now, I've had enough."

If any other member of the family had behaved in a like manner, he would have severely reprimanded that one for a breach of table manners. But as the head of the household, he likes to give

* A kind of medley soup made by boiling rice cakes, fish, and various vegetables together, eaten at new year.

$\dagger$ Cakes made by boiling glutinous rice and beating it in a mortar. 
himself airs of a little despot. Under the circumstance, he sat quite cool before the scorched and broken mochi lying in the mussy juice.

His wife brought out a bottle of Taka-Diastase from the cupboard, and placed it on the table.

"I won't take it," said my master, "as it is not efficacious."

"But then they say it is marvellously good for starch. You should take it," urged his wife.

"Starch or no starch, it does me no good," insisted her husband.

"You are really very changeable," murmured the other.

"No, I am not. It is because the medicine is poor that I do not take it."

"But you did take it everyday until recently, saying it worked a miracle."

"It did me some good then; it does me no good now," retorted my master antithetically.

"If one takes a medicine by fits and starts, as you do, any efficacious medicine is likely to produce no effect. Unless you are a little more patient, you will never get your indigestion cured. For, unlike other complaints, it is of an obstinate nature. Don't you think so?" said his wife, turning to the maid who was waiting on them, with tray in hand.

"Yes, ma'am. You are quite right," joined the maid, taking her side without hesitation; "You 
can't tell whether it's any good or not, if you don't go on trying it."

"Let me alone! I say I won't take it, for so have I decided. What good does woman's counsel do? Put a bridle on your tongues!"

"Yes, I give woman's counsel!" said the mistress, pushing the bottle of Taka-Diastase to him in a manner that meant he was to do her bidding at any cost. But my master rose up in silence and entered his study, while mistress and maid looked at each other, and exchanged a sarcastic smile.

It being very dangerous to follow him and get on his knee at such a time, I judiciously went round the garden, and got upon the veranda of his study. I peeped through an opening between the sliding-screens, and found my master reading a work by Epictetus, if my memory is right. If he could understand that in the state of mind he was in, he would certainly be a wonderful student. But such was not the case. Five minutes had scarcely passed, before he threw the book upon the table with a bang, which was just what I expected. I looked on still intently, and saw him bring out his diary, and make the following entry:-

"Took a walk with Kangetsu to Nezu, Uyeno, Ikeno-hata, and a part of Kanda. Met in front of a machi-ai at Ikenohata a geisha, dressed up in a spring garment with a printed skirt, playing battledoor and shuttlecock. Her dress was beautiful, 
but her face was very plain, looking somewhat like that of our cat."

Now, it seems entirely out of the way to make a special allusion to me in the matter of ugly looks. Suppose I go to Kita-doko, a barber's, to have the hair of my face shaved, the result will be, I am sure, that I shall be of a piece with man, so far as my looks are concerned. The vanity of man is simply astonishing.

When we turned round the corner of Hotan, the druggist, we came across another geisha. She was a slender well-favored girl with delicate shoulders. And the dress of light purple in which she was neatly clad, gave her a graceful appearance. As we passed her, she smiled showing her ivory teeth, and said:-

'Pardon, Gen-chan! I was very busy last night, you know.' It was a surprise that her voice was as hoarse as a frog. This seemed, as it were, to dismantle her beauty to a degree. Indeed, my curiosity to turn around to see what sort of a man a Genchan was, completely died away. We then got out to Onari-michi, I, with my hands in my bosom. Kangetsu was singularly restless."

Nothing is harder to define than the human mind. In what frame of mind was my master at that time? Was he out of temper? Was he in good humor? Or was he smoothing the ruffled brow of care by means of a work of an ancient 
philosopher? No one could tell. Was he scoffing at the world? Or was he desirous to go into society? Was he stirring up his temper for a trifle? Or was he standing aloof of worldly concerns? No one could guess at all. When we come to think of human caprice, we, cats, can not but be proud of our simplicity. We eat when we want to eat. We sleep when we want to sleep. When we are angry, we pour out the vials of our wrath to the last drop. When we are sad, we cry ourselves blind.

Besides we are never in need of such a useless thing as a diary, for we find it unnecessary to make a daily record. It may be useful for a hypocrite like my master, who is given to taking off the veil in seclusion, screened from public observation. As for our family, every action is a faithful register. I think, therefore, we are not required to preserve our true self by such troublesome means. If we have time to spare for journalizing, we prefer to indulge in a nap on a veranda.

"Supped at a restaurant in Kanda. Took two or three cups of Masamune, ${ }^{*}$ the taste of which I had long forgotten. As a result, I feel remarkably well. A little sakè at supper seems an excellent thing for indigestion. Taka-Diastase does no good; truly it is worthless, whatever one may say of it. If medicine it is, it is only an inefficacious one."

* One of the best saké made at Nada. 
He bitterly attacked poor Taka-Diastase, and appeared as if he was quarrelling with himself. He thus gave vent to the passion roused by the petty family dispute that morning.

The real importance of man's diary may be for such cases as this.

"Some days ago, A told me that abstinence from morning meal would cure indigestion. Did so for two or three days. No effect; only a rumbling of abdomen. B advised to refrain from eating pickled vegetables. He was of the opinion that pickles cause a weak stomach, and therefore the best remedy is not to eat them; for, by doing so, the very root of the complaint is cut off. Had not a morsel of pickles for a week. Derived no particular good from it. So began to eat them again. Then I heard from $C$ that massage works a wonder. But not the ordinary massage. It was one of the old school, known as Miyagawa Style. If treated by this massage once or twice, the average indigestion would be thoroughly cured. Yasui Sokken, a well-known scholar of Chinese Classics, he said, was much in favor of this massage, and a hero like Sakamoto Ryuba received its treatment now and again. So I immediately went to Kami-Negishi to try it. But the massagist handled me so roughly,saying that a complete recovery was not to be ensured unless the bones were kneaded, or unless the viscera were once upset, - that I felt more 
dead than alive afterwards, being in a state of stupor. Of course I did not repeat this trying experience. Then D said I must not eat any solid food. So I made a trial, taking nothing but milk for a day. This time the bowels rumbled as if a flood had taken place in them. And I passed a sleepless night. Then E came with his counsel to try to breathe so as to move the diaphragm in a way that would exercise the internal organs. Then it naturally follows, he said, that the stomach will regain its normal function. This experiment also proved a failure. To begin with, it gave a strange sensation of uneasiness. I would suddenly begin to breathe as I was told, but would forget again after five or six minutes. And if I tried not to forget, I could neither read nor write. Meitei, the esthetician, found me in one of these trials, and sarcastically remarked: "Away with your silly effort! You look like a man in throes." And so I have given up this practice also. Mr. F told me to eat soba.* So I proceeded at once to take alternately kaket and mori, $\ddagger$ which resulted in another trouble.

Thus I have tried every possible means in my power to cure my chronic disease, but all in vain. I must not forget to state, however, that the three

\footnotetext{
* A kind of food made of buck-wheat.

$\dagger$ Hot soba,

$\ddagger$ Cold soba.
} 
cups of masamune which I took last night as I supped with Kangetsu, had a decided effect. And I mean to drink the same quantity every evening hereafter."

I am sure that this, like the rest, will not last long. My master's mind is constantly changing like the pupils of my eyes. He is, as this entry shows, very anxious about his complaint, and yet he pretends to be indifferent to it. Is it not funny? The other day, a friend of his, a man of learning, came and demonstrated, from a certain standpoint of view, that all maladies are nothing more or less than the results of the sins of our forefathers as well as those of our own. It was an excellent opinion evidently established on a laborious investigation; for his theory was conclusive, without a shade of ambiguity. Now, my master, I am sorry to say, has no brains or culture to take his stand in any respect against this argument. But since he himself was suffering from indigestion, he apparently thought he was bound to plead his own case somehow or other in order to hold his head up.

"I admire your opinion. But at the same time I must remind you that Carlyle was bilious, too."

My master offered this silly protest as if he deemed it a mark of honor to share the same disease with the great author.

"Though Carlyle suffered from indigestion, a 
sufferer of indigestion does not necessarily make a Carlyle," confuted the man, and silenced my master.

With all his vanity, my master really wishes to be free from indigestion; for he said he would take a little saké at supper from that very evening. Is it not a farce? I think that the quantity of zoni he ate that morning may have been the result of the masamune taken on the preceding night with Mr. Kangetsu. Speaking of zoni, I also felt inclined to have a little.

Though I am a cat, I eat almost anything. Unlike Kurumaya's Black I have not the ambition to make an expedition as far as the fishmonger's in the side-street. Nor am I under a lucky star to live on the fat of the land as is Miss Mikè who belongs to a lady-teacher of a two-stringed harp, who lives on the new road. Consequently I am not particular about my food. I eat the crumbs of bread left by the children. And I taste sweet-meats. Pickled vegetables are not at all palatable, but I once ate a piece or two just to try them. I do not know how it is, but when I once taste, I find almost all victuals eatable. It is more becoming a Sybarite than a cat living in a teacher's house, to insist upon making a choice of food.

According to what my master says, there was in France a novelist called Balzac. He is said to have been a fastidious man not in living, but in 
diction and phraseology, as does credit to one in his profession. One day he was endeavoring to find a proper name for a character in a novel he was writing. But none seemed to suit his fancy. Just then a friend of his dropped in, and they soon went out for a walk. Now, the friend accompanied Balzac, little knowing with what his mind was occupied then. On the other hand, Balzac walked along the streets riveting his eyes upon the signboards of shops, intent upon finding the name he had long sought for his character. Still no name was found to come up to his idea. He walked from one street to another with his friend following him in a state of maze. Thus they wandered through Paris from morn till nightfall. On their way, however, Balzac happened to catch sight of a tailor's sign-board, on which was painted the name of Marcus.

"Hurrah! That's it! Isn't Marcus a glorious name?" he exclaimed, clapping his hand; "Add the initial $Z$ to it, and it makes a perfect name. Yes, it must be Z. Z. Marcus! How fine it sounds! An invented name, however befitting it may seem, has something unnatural in it. I've got an ideal name at last." He was, as is said, in a transport of delight, entirely forgetful of his poor companion. It is indeed not an easy job to have to devote a whole day to the exploring of Paris solely for the 
purpose of naming a character of a novel. Happy are those who can afford to carry their fastidious taste so far.

But such an ambition never occurs to me, who am destined to have an "oyster-like" master. It is my circumstances that make me satisfy my appetite with almost any sort of food. As it is, it was not a sense of fastidiousness that made me feel like eating zoni. It was simply from the idea of getting something to eat whenever possible, that I recollected I might find the wooden cup of zoni left by my master. So I went round to the kitchen.

I found the very mochi sticking to the bottom of the cup exactly as it looked that morning. To tell the truth, I had never tasted this particular kind of food till then. It looked delicious; but at the same time I felt half afraid to touch my tongue to it. With one paw I pushed aside the greens on it. My claws caught a portion of its glutinous coat. I smelt it and found it had an odor not unlike that of scorched rice, as it is ladled from a pan into a rice-tub. I did not know my own mind whether I should eat it or not. I turned round; nobody was there, luckily or unluckily I did not know then. The maid was outside, playing battledoor and shuttlecock happy as the day was long. The children were singing a popular nursery rhyme. Now was the time to eat it, if I wanted it at all. Let 
this chance slip away, and I should have to wait another year to know how mochi tasted. At this juncture, I conceived, cat as I was, a truth: "A rare chance often drives all creatures to act quite contrary to their will."

To tell the truth, I did not care to eat the zoni very much. No! The more I gazed at the strange object at the bottom of the cup, the more a sense of fear grew on me, taking away my very appetite. Had the maid opened the kitchen door, or had I heard the children's approaching steps, I would not have regretted leaving the spot. And not a thought of zoni would have come into my head until the next year. But no one came. I felt as if someone whisper: "Come! come! Why don't you eat it? " I looked into the cup, and actually prayed that somebody would make his appearance without a moment's delay. But in vain. I was thus ultimately compelled to eat the zoni.

At last I stooped in a manner to throw my whole weight into the bottom of the cup, and drove my teeth an inch into a corner of the mochi. The force was calculated to bite off almost anything, but lo! when I meant to draw out my teeth, I found I could not. I attempted a second bite, only to make the matter worse. The thought that mochi has something magical in it did not occur to me until too late. As a man who fell into a swamp 
would only sink deeper with every struggle he made, so my mouth became heavier and heavier with every bite. My sharp teeth were quite helpless. True, they met resistance to a certain extent. But that was all. Things came to a pretty pass!

Mr. Meitei, the esthetician, once sarcastically called my master "an indivisible man," by which he apparently meant a person of dull understanding,- - a witty remark it was. Now, this mochi, like my master, was stubbornly indivisible. Bite after bite seemed to produce no encouraging result, just as by dividing ten by three no final solution is arrived at. Amid this struggle I spontaneously derived another truth: "All creatures intuitively foreknow whether or not a thing agrees with them." Although I had discovered two truths already, no sensation of pleasure was produced in me on account of the infernal mochi, which sucking my teeth, gave me such pain as I thought they would be extracted. If I did not make another decisive effort to escape, the maid might come in at any moment. The children's singing, too, seemed to have ceased. I felt certain that they would dash into the kitchen. There was not a moment to lose. In desperation I shook my tail on all sides, and moved my ears up and down, but to no purpose. Presently I recollected that the tail and ears were things least capable 
of relieving me from my trouble. So I gave up this fruitless experiment.

Then I hit upon a bright plan. It was to sweep off the tormenting object by means of a paw. I raised my right paw and rubbed about my mouth. The grasp of the monster was as firm as ever. I then stretched out the left, and gave a violent circular stroke. This disenchanting practice proved powerless to free me from the spell. With admirable patience, however, I went on repeating the trial, first with one paw and then with the other. No encouraging sign! - my teeth were still in the clutch of the accursed mochi. Growing impatient, I put both paws into action, when, behold! for the first time in my life I found myself standing on my hind-legs. I felt then as if I were not a cat. Cat or no cat, it did not matter a bit in that dreadful situation. My one thought was to fight until I completely dispelled the tenacious magical influence of the mochi. Thus resolved, I scratched about my face like one mad. The violence with which I moved my paws very often caused me to totter nearly to my fall. To prevent this I had to keep my balance with my hind-legs, making it hard to remain in one place. So I jumped about the kitchen to and fro. I could not but wonder myself how I kept this unnatural posture so skilfully. A third truth flashed across my mind: "Danger calls 
forth an ability to perform what seems impossible on ordinary occasions. This might be called Heaven's help."

Now that I obtained Heaven's help, I redoubled my energy to fight against the abominable mochi. In the course of the struggle, however, I fancied my ear caught the sound of steps approaching from a back room. The thought of being found in this plight! Like madness itself, I ran about the kitchen. The steps sounded nearer and nearer. Alas! Heaven's help was not given me liberally; the children found me at last!

"Halloo!" they called out in a loud voice. "The cat is dancing with mochi in his mouth!"

The first one who heard the alarm was the maid. Throwing aside her battledoor and shuttlecock, she rushed into the kitchen, and cried, "My!"

"What a cat, to be sure!" exclaimed the mistress who appeared upon the scene in a crested haori of crape. Even the master came out of his study, and flung upon me his customary "Blockhead!"

"It's funny, very funny!" shouted the delighted children. And all the household roared at me with one accord. I got excited, felt distressed, and was unable to stop my dancing. I was at my wits' end. Their laughter was about to subside, when the little girl of five observed: "Mamma, the cat is very meddlesome, isn't it?" This brought about another 
loud laugh, as a roaring billow follows the preceding one. Although I have witnessed many an evidence of human hard-heartedness, I was never so bitterly stung to the quick as I was then.

In the meantime Heaven's help abandoned me, for I came on all fours again, my eyes convulsively turning up and down at this extremity. What a sight it must have been! Unfeeling as he was, my master did not like to see me die in cold blood.

Take the mochi away from him! " said he to the maid. The latter significantly glanced at her mistress as much as to say, "let him dance on." But the mistress stood silent; she wished to see me dance, but not at the cost of my precious life.

"Make haste and relieve him, woman! or he will be stifled to death!" came my master's second command. With a reluctant obedience, as if she had been awakened to work from a pleasant dream in which she was in the midst of eating luxurious food, she took hold of the mochi, and gave it a hard pull. As in Mr. Kangetsu's case, I felt my front teeth, not one but all, would give way. You see, they were stuck fast into the mochi, and the pull was so brutal. Just imagine how painful it was. "Happiness must pass through affliction." Realizing this fourth truth, I looked around as free as air. There was no one about but myself.

Feeling rather small to stay at home and show 
my face even to the maid after such a humiliating event, I took it into my head to pay a visit to Miss Mikè. You know where she lives. I got out into the yard from the kitchen. Miss Mikè is noted for her beauty in the neighborhood. Though I am a cat, I know pretty well what the softer passions are. It is sometimes hard to endure the sight of my master's disagreeable face, and to be snarled at by the cross maid. On such occasions I usually leave home to see this friend of the opposite sex and carry on various conversations with her. Then I soon forget all my cares and troubles, and am refreshed and cheered, up making me feel like a new cat. Wonderful is the soothing influence of the fair sex!

Well, I approached the hedge, and looked through a gap in the hope of finding her in. Yes, there she was! She was gracefully seated on the veranda with a new collar on, it being the New Year. Oh, how exquisite her round back looked! It displayed an ideal beauty of curved lines. The tail that was shapely bent, the paws delicately folded, the ears quivering softly, - all these formed a beauty beyond the reach of art. But what I admired above all was her fur. She was sitting warm and snug bathed in the bright sun, as still as a statue. Yet her smooth velvet coat reflecting the New Year's sun, seemed tremulant, though there 
was not a breath of air. For a few minutes I was lost in admiration.

"Miss Mikè! Miss Mikè!" I called in a low voice when I came to myself, making a sign with my paw.

"Oh, is it you, Professor? "she said, coming down the veranda; a small bell which was attached to her red collar tinkled. "Ah, she has got even a bell," I thought, "to welcome the dawn of the New year. How sweet it sounds!" While I was admiring its melody, she drew near me. She greeted me with "A Happy New Year to you, Professor!" and shook her tail to the left. Our way of saluting each other is to erect the tail like a pole and then wheel it to the left.

Among all the neighbors Miss Mikè is the only one who calls me by the name of "Professor." As I said before, I have no name yet. But living in a teacher's house, the polite Mike always gives me that honorary title. It is not bad at all to be addressed in that way; so I am glad to respond to the title.

"I wish you the same! How beautifully you are done up!"

"How do you like my bell? My kind mistress bought it for me at the close of last year. Isn't it nice?" And she made it tinkle and tinkle.

"Yes, its sound is nice and sweet. I have never 
seen such a splendid thing in all my life."

"You don't say so! Lots of us are provided with them." Again she gave it tinkles. "Isn't it melodious? Oh, I am so happy!" And tinkle after tinkle came in rapid succession.

"Your mistress thinks a world of you, doesn't she?" I asked in an envious mood, reflecting on my own lot.

"Yes, she does; she holds me as dear as her own daughter," she answered frankly and laughed an innocent laugh.

Now, even the cat is not devoid of the power of laughing. Man is laboring under a false impression in thinking that the act of laughing is peculiar to his species. Our way of laughing is to contract the nostrils into a triangular form, while vibrating the hyoid, which of course he cannot understand.

"What is the master of your house, may I ask?"

"The master of my house, do you say? That sounds strange. Say lady teacher! She is a teacher of a two-stringed harp, you know."

"That I know. What I want to know is of her lineage. I dare say she was a lady of rank in the days past."

"Yes, she was."

"I will remain in a pine grove and abide the coming of my lady 
Within the paper-slides the teacher was heard to begin singing and playing on her two-stringed harp.

"Isn't her voice musical?" said Miss Mikè, with a look of pride.

"Yes, so it seems to me. But I do not understand music very well. What is that?"

"Do you mean the song she is singing? That is, what do you call it? - a song that my mistress is very fond of. Do you know her age? She does not look very old; but she is in reality sixty-two years of age. Isn't she very hearty and hale?"

She must be hearty, considering she is still on this side of the grave at that advanced age.

"Yes" was all I said. I knew the reply was dull and blunt. But I could not help it, as I had no smart one ready on the spur of the moment.

"Though she is not well off now, she is nevertheless descended from a respectable family, as she has often told me."

"Indeed, what was she in the old days?"

"If I remember rightly, she is Tenshoin's secretary's sister's mother-in-law's nephew's daughter."

"Beg your pardon?"

"Why, Tenshoin's secretary's sister's ......."

"Wait a bit, please! Tenshoin's sister's secretary's

"No, no, you are wrong. Tenshoin's secretary's sister's 
"Now I understand. She is Tenshoin's?"

"Yes."

"Secretary's?"

"Yes."

"Nephew's ....?"

"No, no, mother-in-law's."

"Yes, yes, I see. Mother-in-law's?"

"Yes, mother-in-law's nephew's daughter."

"Mother-in-law's nephew's daughter, eh?"

"Yes, now you understand?"

"Well, not clearly. It's rather confused, and I cannot yet see the point. In short what relation is she to Tenshoin?"

"Ah, you are slow of understanding. Haven't I been telling over and over that she is Tenshoin's secretary's sister's mother-in-law's nephew's daughter?"

"That I fully understand. But ......."

"If you understand that, isn't it enough?"

I could not but yield with an affirmative answer. There are times when we are compelled to tell a fib pressed by the force of reasoning.

The sound of the harp suddenly ceased, when the voice of the music teacher was heard calling: "Mikè! Mikè! It's tiffin time."

"Listen! My mistress is calling me. May I go home now?"

I could not very well say "no." 
"Well, good bye! Come round again!" she said and hurried back through the garden, tinkling her bell. She had not gone far, however, before she abruptly retraced her steps and remarked anxiously: "You do not look at all well. Is anything the matter with you?"

I did not dare confess all that had happened to me in my attempt to eat zoni, and how I got into trouble.

"No, nothing ails me in particular. I had to think over a little question, and as a result my head ached. Counting upon your company to set me all right again, I came to see you."

"Oh, indeed! Take good care of yourself. Adieu!"

She took her leave not without some hesitation. Sweet cat! She entirely drove away the trouble I had with mochi, leaving me happy and cheerful.

I thought of passing through the tea-garden on my way back, and made my way to a bamboofence, treading on the frost which was beginning to melt. When I put my head out of a breach in the fence, my eyes fell upon Kurumaya's Black, who was making a mountain of his back in a hearty yawn, on the frost-bitten chrysanthemums. Now, I am no longer so timid a cat as to feel any fear of meeting him. But it is a nuisance to go into his 
way. Under the circumstance, I was going to pass by, pretending that I had not noticed him.

"Here, you nameless cat!" growled Black, whose nature it is never to allow anyone to pass unchallenged when he thinks he has been slighted.

"How high you hold your head of late! There's nothing to be stuck up about in being a teacher's cat. Out upon your big looks, humbug!"

Black was apparently ignorant of the fame I had attained, but explanation was useless for one so wanting in sense. I thought it best, therefore, to give him a formal salutation and to get rid of him as soon as possible.

"A happy new year, Mr. Black! I am glad to see you in your usual good spirits." So saying I erected my tail and drew a semi- circle to the left. But the rude wretch did not return the salute; he only kept his tail standing.

"Happy new year? Fie! Congratulations on the New Year, but idiots are to be congratulated all the year round. And you are one of those pretty fellows. Look sharp, you ninny-hammer!"

The word "ninny-hammer" was taken for abusive language; but I could not quite understand what was implied.

"I should like to know what you mean by "ninny - hammer."

"Pshaw! The idea of inquiring the sense of the 
word by which you yourself are ridiculed! I declare, therefore, you are a nincompoop!"

"Nincompoop" sounded rather poetical, but as to its meaning I could understand it no better than I had "ninny-hammer." In fact, this was more indigestible than the other. I wished to know what it meant for future benefit. But expecting no definite explanation from the ignorant fellow, I stood in silence face to face, feeling a little awkward. Just then a loud shrill voice came from Black's mistress: "Goodness gracious! A piece of salted salmon that I put on the shelf is gone! It's that accursed Black that has carried it away, I am sure. Plague upon 'nem! The beast will have reason to remember this." The still balmy air of the early spring rang with her boisterous cry, and seemed, for a time, to drive away the charms reigning over all nature. Black remained cool and indifferent. There was in his look an expression of mockery which seemed to say: "Keep crying to your heart's content, foolish woman!" He stuck out his square chin as if to inquire whether I had heard that cry or not. My attention had hitherto been too much occupied by his prittle-prattle to care for anything else; but now I caught sight of a muddy bone lying under his paws. It was evidently a relic of a piece of salted salmon worth about two sen and three rin. 
"Ah, you live as usual by your wits!" I exclaimed admiringly in spite of myself, forgetting all that had happened between us. But Black was not to recover his humor by such a compliment.

"Live by my wits? Confound you! Do you think I set my wits to work for a piece or two of salted salmon? I am not that kind! Do you know to whom you are talking? I am Kurumaya's Black!" And the quarrelsome fellow raised his right paw and stroked the other up to the shoulder in a threatening manner, as a man rolls up his sleeves for a fight.

"I know full well that you are Mr. Black."

"Then why did you insult me? Why did you dare say I lived by my wits?" He spit at me furiously, which, if applied to man, would stand in place of being shaken by the coat collar. I was thrown off my balance and knew not what to do. Fortunately a noisy cry from Mrs. Kurumaya was again heard rending the still air: " Halloo! Nishi kawa-san! I want you, man. Are you deaf? Bring a pound of beef, and that immediately. Be sure you don't forget. A pound of beef, I say again. And mind it's not tough."

"What a noise she makes over a bit of meat!" scoffed Black, stretching his legs: "The idea of loudly announcing to the neighbors the purchase of a pound of beef, and that not oftener than once 
a year! Nothing can be more absurd!" I kept my tongue between my teeth, being at a loss as to what to say.

"I am not quite satisfied with that small quantity; but it can't be helped. Take it, woman, and I will soon despatch it." The rogue spoke as if the meat were ordered for his own meal.

"You are to enjoy a regular treat this time. Isn't it very fine?" I observed encouragingly in order to make him go off.

"Hold your tongue! It's none of your business." As he growled, he kicked the ground with his nimble hind-legs, and sent a shower of thawing frost over me. I was quite taken by surprise. While I was shaking myself free of the muddy drops, Black crept under the fence and disappeared. No doubt he went to seize hold of the beef Nishikawa was to bring.

When I got home, I found things unusually lively, and the unwonted merry laugh of my master fell upon my ear. Wondering at this novel phenomenon, I leaped upon the open veranda and made for my master's side. Near him sat a stranger dressed in a crested haori of cotton and a skirt of a stuff called kokura-ori, a style indicative of a student. He had his hair neatly parted, and he looked very sober. At the corner of a brazier, lying side by side with a cigarette box of Shunkei 
lacquered-ware, was a card with these words:"I have the pleasure of introducing Mr. Tôfū Ochi to you. Kangetsu Mizushima."

Thus the card gave his name as well as the fact of his being a friend of Mr. Kangetsu's. Although unable to trace the thread of conversation which was going on between host and visitor, having come in in the middle of it, it appeared to be about Mr. Meitei, the esthetician, to whom I introduced my readers before.

"And he urged me," said the visitor calmly, "to go with him, declaring he had conceived a bright plan."

"You don't say so!" exclaimed my master, offering the other a fresh cup of tea; "A plan about taking a noon-meal at a foreign restaurant?"

"Well, I, like you, failed to make out at that time what he meant by his plan. But knowing his ways pretty well, I thought he was up to some humorous trick

"Really! And you went along with him?"

"Yes, and hereby hangs a tale."

"I am not a bit surprised to hear that you were made game of." This was what my master thought when he gave me a smart tap on the head; I was sitting on his lap.

"I presume he acted a farce as usual. That's the worst of him," said my master, suddenly recalling Andrea del Sarto. 
"Yes, and he said, 'Let's take some novel dishes."' "What did you take?"

"To begin with, he entered upon a discourse concerning foreign cookery, with his eye resting upon the menu."

"Previous to ordering any dishes?"

"Yes."

"What did he do next?"

"He shook his head, and turned to a waiter, saying there was nothing new in the bill of fare. The waiter who was a little chagrined, called our attention to the roast duck, veal chop, etc.. But Mr. Meitei observed that we had not come all the way to be served with such tsukinami.* The waiter, to whom the term was Greek, stood speechless with a vacant look."

"I should not wonder."

"Then turning to me, he continued in highflown language: 'In England or France one can easily feast on Temmei $\dagger$ verse or Man-yô verse, whereas in Japan a menu is everywhere of the same stamp. Consequently I do not feel at all like dining at a restaurant.' By the by, has he ever been abroad?"

* Commonplace verse. Here humorously applied to ordinary meals.

$\dagger$ Ancient poems reknowned or their refined style and elegant thought. Used here for a luxurious fare. 
"No, no, nothing of the sort! He has never been off his native soil. But he has time and money enough to afford to do so anytime if he wants to. Very likely he made use of his anticipations in place of his recollections just for the fun of it."

Thinking he had cracked a good joke, my master laughed aloud himself to provoke the visitor's humor.

"Is that so?" said the stranger, who did not appear to appreciate the joke very much.

"For my part, I thought he had once made a trip abroad, though I knew not when. So I listened to him seriously. Besides, I was led to believe him by the manner in which he described a slug soup and a frog stew as if he had really tasted them."

"May be, that was a second-hand story. He takes the cake for telling fibs, you know."

"Yes, I should say so!" responded the guest, casting a glance at the daffodil in a flower-vase. I fancied I saw something approaching chagrin on his face.

"Was that what he called a bright plan?" questioned my master in a manner to draw an affirmative answer.

"No, sir. That's a mere introduction: the main subject is yet to follow."

"Hum!" put in my master with curiosity. 
"He then sought my wish, saying: 'As you know, such dishes as slug and frog can not be had here for love or money. What do you say, therefore, to satisfying ourselves with such a dish as tochimembo?' So I, without a moment's thought, replied, "we may as well take it."

"'Tochimembo!' Isn't that a strange dish?"

"Yes, really it is. I could not but take it in earnest then, as he looked so serious," said the visitor in a tone as if begging my master's pardon for his lack of attention.

"What happened then?" inquired my master bluntly, manifesting little sympathy for him."

"He then ordered two of the strange plates to be brought. The waiter asked if it was not menchbô (the Japanese for mince-ball, you know) that we wanted. 'No, it's not mench-bô,' corrected Mr. Meitei, with as arch a look as could be. 'It's tochimembo that we order."

"Indeed! There isn't such a thing, is there?"

"Well, no, I, too, began to be suspicious. But he looked as grave as a judge. And besides, what with the fact that he is very well acquainted with things Occidental, and what with my firm belief that he had once been abroad, I was led to accept his words as true. So I joined him in repeating to the waiter the thing in question."

"And what did the waiter do?" 
"He reflected a while-it is very funny when I think of it now - and said to us that he was sorry to have no tochimembo ready that day, but as to mench-bô we could each have it immediately. Mr. Meitei looked very much disappointed, and said to him: 'What a shock! We've come on purpose to take that particular dish. I beseech you, my good lad, to oblige us by arranging to give us satisfaction.' And he gave a twenty sen piece to the waiter, who went downstairs, saying he would at any rate consult with the cooks over the matter."

"Dear me! He seems to have had an unusual appetite for tochimembo."

"After a while, the waiter reappeared with a humble bow and excuse. He said, however, that if we would give a special order for it, they could let us have it, on condition that we wait for some time. 'In this festive season, we've got nothing particular to do,' said Mr. Meitei with calmness; 'so we may as well wait and eat it.' And he took out a cigar from his pocket and began to smoke leisurely. Having nothing else to do, I produced the Nippon and commenced reading it. Then the waiter went downstairs again apparently to have another consultation."

"How troublesome it was!" rejoined my master, pressing forward with as much interest as he would show in reading a war correspondence. 
"A few minutes later, the waiter made his appearance again. 'I am very sorry to confess, sirs,' he apologized, entering into sympathy with our feelings, 'that, on account of the scarcity of the materials for tochimembo, we cannot obtain the needed supply even at Kameya's on the Ginza or at No. 15 in Yokohama. Such being the case, the dish you want cannot be prepared for some days yet.' 'So much the worse! We've come here in vain after all!' repeated Mr. Meitei, turning to me with a discontented look. As you see, I could not very well remain silent; so I chimed in, 'It's too bad! Oh, what a pity!"

"You were right," agreed my master. But I failed to see why he was right.

"Then the waiter who seemed to feel sorry for us, proposed that we come again some day when they had the materials on hand. 'What materials do you use?' returned Mr. Meitei. To this question the waiter only responded with a singular laugh. 'Isn't it formed of hai-ku-ka of the Nippon style?' he demanded. 'Yes, so it is, sir,' retorted the waiter; 'consequently it's not easily procured even in Yokohama. I am very sorry, sir, that we are unable to comply with your request at present."

"Ha! ha! ha! It's very amusing. And is that the end of your story?" asked my master, laughing louder than ever; in fact, I was nearly shaken off 
his lap. He laughed so hard that he forgot me. Perhaps the thought he had not been the only victim to Meitei's tricks, made him give way suddenly to mirth.

"When we got out from the restaurant, he triumphantly observed: Here, now! Didn't the fun work well? The nom de plume, Tochimembo, was so splendidly turned to account!' I admitted it was admirable, but to tell the truth, I was very hungry when I parted from him, as the time for lunch had long passed."

"How hard it must have been, I am sure!" My master sympathized with Mr. Tōfū for the first time. And I did agree with him in this point. There was silence for a time, and my purring alone was heard.

"Well, Professor, I have a favor to ask of you, and therefore gave myself the pleasure of calling on you." Mr. Tōfū broke the silence in an altered tone, drinking up the cold tea before him.

"Aha, what is it?" returned my master, assuming as consequential a look as the other.

"You see, I am very fond of the arts and literature, and ......."

"That's very good," encouraged my master.

"A number of us having the same tastes have started a Recitation Society. We are to meet once a month with the object of improving ourselves in 
that line of culture. And the first meeting was actually held at the end of last year."

"Just tell me what you mean by your 'Recitation Society.' Is it a sort of elocutionary exhibition in which they recite selections of prose and poetry, practising modulations of the voice?"

"Well, yes. That's about it. We mean to begin with productions from ancient authors, gradually coming down to modern works, including the original compositions of our members."

"Do you mean by productions from ancient authors such as Biwa-kô by Hakurakuten?"

"No."

"Are they then such as Shumpū Batei no Kyoku by Buson?"

"No."

"Pray, what style of work was chosen at the last meeting?"

"A tragedy by Chikamatsu."

"Chikamatsu? Do you mean that dramatist?" There existed but one Chikamatsu in the world. The name suggests at once the identical Chikamatsu, the dramatist. I thought my master very stupid to question the fact which is as clear as day. But in blissful ignorance, he was stroking my head tenderly. In this world of blunders, however, where there are some who rush to interpret a glance from a squint-eyed lady as something 
sweetly significant, such an instance as this might not be deemed striking after all. Thus thinking I allowed him in happy content to stroke on.

"Yes, I do," replied Mr. Tōfū, looking into my master's face.

"Was it delivered by a single man, or did many take part?"

"We had it performed by several, each representing one character. The first principle we aim at is to have deep sympathy with the characters of a work so that we may reveal their individualities. To this we add gestures. In the case of a dialogue we attach great importance to exhibiting persons belonging to a particular age. For instance, if the part of a young lady or an apprentice is to be played, we must try to appear really as such."

"Then it is little different from a theatrical performance?”

"Yes, only there are no proper costumes or scenes in our case."

"Excuse my asking you, but was your effort successful?"

"Well, yes, I should say it was a success, considering we performed for the first time."

"And what sort of tragedy was it that you had last time?"

"It was the scene of a boatman carrying an okyaku to Yoshiwara." 
"What a scene, to be sure!" exclaimed the worthy educationist, shaking his head slightly. A puff of smoke of Hinode wound about my ear, and then came round my cheek.

"No, sir, it was not so unusual. And the dramatis personae comprised only okyaku, boatman, oiran, nakai, yaritè, and kemban," said Mr. Tōfū, in a calm tone.

At the word oiran my master made a wry face. But the terms nakai, yaritè, and kemban being evidently beyond the reach of his conception, he soon proposed a series of questions.

"Is a nakai a maid of a brothel?"

"I've not yet made inquiry. But I think a nakai is a maid of a waiting house, while a yaritè is something like an assistant in a brothel." Mr. Tōfū declared a moment ago that each character was to be represented as near to life as possible. Notwithstanding this, he seemed to lack definite knowledge of the office of a yaritè and a nakai.

"Now I understand what these two kinds of women are. My next question is about a kemban. Does it indicate a human being or some particular place? And taking it to be a human being, is it a man or a woman?"

"If I am not mistaken, it is a human beinga man."

"And what is his office?" 
"Well, I have not yet extended my investigation that far; but I will make inquiry by and by." I felt pretty sure that a dialogue participated in by such a performer would end in a farce. I lifted my eye just to see how my master looked. There was a sober expression on his countenance.

"And what were the other reciters?"

They were of different professions. The part of an oiran was played by Mr. K,-B. A.. It was rather queer to hear him, a gentleman with a moustache, drawl in an effeminate tone. Besides, there was a scene in which the oiran was to fall into a swoon, and .......

"Was it required even in a recitation to go so far as that?" asked my master anxiously.

"Yes, you know, expressive gestures are very important after all," returned Mr. Tōfū, with the air of a man thoroughly versed in the details of the stage.

"Did the swooning come off successfully?" was my master's pointed question.

"No, it was a failure at the first meeting," as pointly answered the visitor.

"And what was your rôle?" asked my master.

"Boatman."

"Played the part of a boatman, you say?" My master's tone sounded as much as to say, "If you could represent a boatman, even I could have been 
equal to act the part of such as a kemban." "And was the boatman well acted?" asked my master point blank. Mr. Tōfū did not seem to take offence. His tone was as calm as ever when he said, "The undertaking went up like a rocket and came down like a stick through the failure of the boatman. To tell the truth, there lodged next door to where we met four or five bluestockings, who found out somehow or other that we were going to hold a meeting of recitation. They came under the window and were evidently watching our performance. As I began to feel gradually at home in the imitation of a boatman, I became spirited and encouraged, and was just getting into full swing, when a roar of laughter burst upon my ear: perhaps I gesticulated too freely, and made it hard for them to keep their countenance. O but I was taken aback! How abashed I was! After this sudden interruption, I could not go on smoothly, do what I would. And the meeting was abruptly broken up."

Mr. Tōfū avowed a few moments ago that the Recitation Society had made a good start. How could he see it in that light? On the contrary, I could picture to myself the sorry plight in which the meeting had been closed. I made an effort to look grave, but in vain; my hyoid would roll in spite of myself. My master stroked me on the head 
more and more tenderly. I experienced a strange sensation of gratitude and uneasiness at being thus caressed for laughing at his guest.

"What a mishap!" condoled my master. He began his New Year with a word of condolence!

"We are going to try our best to make the second meeting a more splendid and worthy one. To tell the truth, I called on you to-day, Professor, with no other object than to ask you to join us and help to further the interests of the Society."

"But such as swooning is beyond my power." My master who is always of an inactive spirit was going at once to withhold his assent.

"No, you are not called upon to do such things. Here is a list containing the names of the supporters," said Mr. Tōfū, taking out a small octavo volume importantly from a purple wrapper, which he opened and placed before my master. "I should be happy if you would kindly add your signature and seal to this."

I saw in this book, arranged in good order, a list of the names of well-known M. A.'s and B. A.'s of the time."

"Well, I may as well become a supporter. But first tell me what obligation I am to enter upon," asked the sluggish professor, in an anxious mood.

"You are not necessarily bound to do anything in particular. It would be enough for us if 
you would grant us the favor of adding your name to the list in token of your approval."

"Then I will accept your proposal," said my master in a lighter tone, now that he was informed that he was to be under no obligation. His face indicated that he would even sign a compact for a rebellion with the one condition that he should not incur any responsibility. It was really a notable occasion for my master to have his name recorded side by side with renowned men-of-letters of to-day, - a great honor which would seldom, if ever, fall to his lot again. No wonder his words had a merry jingle in them.

"Excuse me a minute," said my master, dropping me off his knee, and going into his study for his seal. Mr. Tōfū took this advantage to pick up a piece of sponge cake from the cake-dish, which he crammed into his mouth in a jiffy. For a time his jaws moved in a heavy uneasy manner. The sight reminded me of the mochi that went hard with me that morning. By the time the sponge cake had been made away with by the guest, my master came out of his study, seal in hand. He was apparently unaware that one piece of cake was missing from the dish. Or I should have become the first object of his suspicion.

When my master entered his study again after Mr. Tōfū had gone, he found a letter from Mr. Meitei waiting on his table. 
"I wish you a Happy New Year.....

My master thought the letter was begun with unusual formality, for he had seldom received one of serious nature from that gentleman. To give an example, the one he sent the other day was to the following effect:- "Just a few lines to inform you that I am now enjoying peaceful days for the most part, as no girls have fallen in love with me, nor disturbed me with love-letters since I saw you last. I beg you, therefore, to set your mind at ease."

Compared with the note foregoing the one in question was exceptionally conventional.

"Contrary to the negative policy which you always hold, I have taken measures as positive as possible to greet the dawn of an unusually glorious New Year." Just imagine how busy I am everyday; I have actually no time to look you up .......

My master inwardly admitted this true, thinking a man of his disposition would have a run of jollifications at this special season of the year.

"Yesterday I stole a little of my busy time to treat Mr. Tōfū to tochimembo. But as ill luck would have it, they were out of materials for the dish. It was a thousand pities that this circumstance frustrated my intention

The letter was resuming its usual strain by degrees, thought my master. And a smile flitted over his face. 
"I am going to attend Baron A's card party to-morrow, and the day after, a New Year's banquet of the Esthetics Society, and the day after, a welcome meeting for Prof. Toribè, and the day after, .......

My master skipped over a few lines with an exclamation of "nuisance!"

"As you see, I shall have to put in an appearance at a series of meetings, such as of Utai, Haiku, Tanka, Shintai-shi, and what not. So that I have many irons in the fire for the present. This accounts for this letter of greetings. Do not take it amiss, if you please, that I am unable to go and see you......."

"You are not necessarily required to come to see me," said my master, as if in reply to the letter.

"It is long since we sat at the same table, so I mean to have you dine with me next time you come. There will be nothing special to please you; but I will see that you have at least the dish of tochimembo......"

"Pish! The old fox is still at tochimembo," cried my master who was offended a little.

"In case the dish should fail to be prepared on account of the recent scarcity of materials, I will try to treat you to the tongues of peacocks......."

"Ah, he has an alternative in reserve," said my master who was curious to read on. 
"As you know, the quantity of that particular delicacy obtainable from one peacock is not half as large as your little finger. So in order to satisfy an appetite like yours ......."

"Stuff and nonsense!" rapped out my master.

"I must get at least thirty of them. Though we find a few of these birds at the zoo, or Hanayashiki in Asakusa Park, the worst of it is they are not to be obtainable at common bird fanciers. And I am very much troubled about it......."

"You are troubling yourself unasked," said my master, not a bit thankful.

"The cooking of peacocks' tongues was once in great prevalence among the ancient Romans when they were in their best days. Imagine! I always thought it the height of luxury, and my mouth often waters at the thought...."

"Imagine? Hang it!" cried my master, in a very cold tone.

"Later, in the sixteenth and seventeenth centuries peacock was an indispensable item of delicacy on the public table throughout the whole of Europe. If I remember correctly, the same birds were served by the Earl of Leicester when he invited Queen Elizabeth to Kenilworth Castle. In a picture of a banquet by Rembrandt, a famous painter, a peacock with its beautiful tail coverts spread, is represented lying on the table......." 
"Seems he is not so busy after all," complained my master, "when he has time to pen the history of the cooking of peacocks."

"Be it as it may, with the succession of feasts I am having of late, I have good reason to fear that I, however strong, shall one day find myself weakened in my digestive organs as you are......."

"How dare he say 'as you are,' as if I were a living specimen of indigestion!" murmured my master.

"According to historians the Romans are said to have feasted twice or thrice a day. Now, if a man sits down to a sumptuous repast so often, he is sure to get his digestive organs out of order, however strong they may be. And the result is indigestion, such as you have......."

"As you' again! Rude beast!"

"They went deep into the question, however, of reconciling luxury with health; in fact, they thought it necessary to indulge in an extraordinary quantity of delicious food, and at the same time to keep their digestive organs in normal condition. And they succeeded in finding out the secret...."

"That's strange!" said my master, with a sudden flush of eagerness on his face.

"They made it a rule to take a bath after dinner. And then by way of cleansing the stomach 
they practised vomitting according to a certain manner. After they had made a clean sweep of all its contents, they would sit again at the table and 'play a good knife and fork' at luxurious meals. Then they went over the same procedure. By this means they managed to satisfy their cravings and still keep the digestive function as active as ever. I consider this a good example of killing two birds with one stone......."

"Yes, it's killing two birds with one stone," observed my master, with an envious look.

"It goes without saying that the Twentieth Century is an age of active human intercourse with a decided increase of public entertainments. It is particularly the case with the rising nation of the East, which has now entered into the Second Year of Japan-Russia War. I believe it is high time for us, victorious people, to get to work in earnest to discover at any cost the art of keeping the digestive organs in order after the manner of the old Romans. For I fear very much lest the mighty nation with its brilliant prospects should be reduced in the near future to dyspeptics, such as you are now...."

"As you are' again! He is really provoking."

"I think it is the duty of those acquainted with the manners and customs of western lands to institute research into old histories and traditions, and recover the secret method in question 
from oblivion, and introduce it into the community of the Meiji Era. By this means they can attain the double end of 'nipping the trouble in the bud,' and paying the debt of the indulgent life they have led...."

"Things are assuming a strange aspect," said my master, shaking his head.

"With this object in view, I have for some time been dipping into the works of Gibbon, Mommsen, Smith, etc.. My effort has been so far discouraging, I am sorry to say, not a clue having been found to any discovery. But, as you know, I am not a man to scotch the snake and not to kill it. When I once try my hand at anything, I am never at rest until I give the finishing touch to it. I have no doubt, therefore, that before long I shall have the satisfaction of seeing an effective vomitting method re-established. You may rest assured that I will let you know as soon as I find it out. Such being the case, I should like to put off, if possible, my invitation to the dishes of tochimembo and peacocks' tongues mentioned before, until after my discovery.

Trusting this arrangement will be equally convenient to you who are actually suffering from indigestion.

Sincerely yours, Meitei." 
"Dear me! I've again nibbled at the bait," said my master. "His way of writing was so serious that I was prompted to read it all through. Meitei is a great idler," he continued smiling, "to play such a trick at the very beginning of a New Year."

Four or five days have passed away since then without the occurrence of any event worth mentioning. The daffodil in the white vase began to wither gradually; and a dwarf plum-tree with its green stem followed to bloom slowly in its small pot. The flowers were attractive, but I soon grew weary of staying at home all day and looking at them. Therefore I went out to see Miss Mikè once or twice. Neither time could I see her. At my first call I thought her absent; but at the second I learned that she was laid up with an illness, for I overheard the following conversation between the music teacher and her maid, from the shade of the haran growing near the wash-stand.

"Has Mikè taken any nourishment?"

"No, she has eaten nothing since morning. I made her sleep snug and warm by the hearth."

The treatment was more becoming a human creature than a cat.

On one hand, I felt deeply my own lot and envied her, but on the other, I experienced some joy in finding that the cat I loved was so kindly treated. 
"That's too bad! Loss of appetite pulls one down awfully, you know."

"Quite true, ma'am. Even I am unfit for work on the day following a fast."

The maid made this reply as if a cat were a being superior to herself. In reality, the cat seemed to be a more important member in this household.

"Have you given her medical attendance?"

"Yes, ma'am. But the doctor was a very curious man. When I went into his office with Mikè in my arms, he asked me if I had caught cold, and was about to feel my pulse. I told him that, not I, but the cat was the patient, and made Mikè sit up on my knee. 'I don't know how to doctor a cat,' he said, smiling a strange smile. 'Leave it alone, and it will soon get well.' He was too unkind. Of course I got angry and said I would not again request him to treat her, and that he knew not how dear the creature was to its owner. Then I took Mikè in my arms again, and hurried off."

"Hon ni ne!"*

Is not "hon ni ne" elegant? I hardly expect to hear such an expression from my folk. It only comes from the lips of such venerable ladies as have distant relationship to Tenshoin.

* It corresponds to "Really!" only perhaps a little more elegant. 
"Hark, isn't she breathing hard?"

"Yes, ma'am. Surely she is having a bad attack of influenza and sore throat. Anyone is likely to get one's throat hurt by coughing, when one has caught cold."

Her language was absurdly polite; perhaps it was suitable to a maid of the dame who is a distant relation to Tenshoin.

"And we have of late a malady which goes by the name of consumption, you know."

"Yes, ma'am, indeed we shall have to keep a sharp look out when such new diseases as consumption or pest are steadily increasing in number as of late."

"There's practically nothing good among things which were unknown in the Tokugawa Shogunate. Therefore you must have your eyes open."

"Really I must, ma'am," said the maid, with deep emotion.

"You said just now that our pet had caught cold. But she has not gone out very often for rambles, has she?"

"Well, yes, she has, ma'am. You know, she has had a bad play-mate lately," said the maid, with consequential looks as if she were about to disclose a State secret.

"Bad play-mate?" 
"Yes, it is a dirty male cat owned by a teacher living on the front block."

"Do you mean that teacher who makes such a rude gruff noise every morning?"

"Yes, I do. The same man who gaggles whenever he washes his face like a goose about to be hung."

The simile used by the maid was apt. My master has a habit of producing a strange noise by thrusting the stem of his tooth-brush into his throat, when he gargles in the bath-room every morning. When in ill humor, he gaggles desperately. When in good humor, he gaggles louder than usual with redoubled vigor. So his noisy gaggling is heard all the same, no matter in what state of humor he is. According to my mistress, her husband did not have that habit until just before the family removed to the present house. It was by mere chance, so she says, that one bright morning he began that practice, which he has followed ever since with remarkable regularity. It is anything but a desirable habit. And why he steadily sticks to it, is more than I can understand. Returning to my personal concern, to call me a "dirty cat" was too much. I still pricked up my ears and listened to their conversation.

"I wonder what good he gets from his gaggling noise. In the good days of the Shogunate, even a 
chugen* or a zori-tori ${ }^{*}$ used to observe respectable manners to a certain extent. In fact, there was not to be found a man in any quarter of samurais' residences who made such an odious noise when washing his face."

"It may well be imagined, ma'am."

The maid was all attention, chiming in with occasional "ma'ams."

"A cat owned by such a master cannot possibly be a good one. Give it to him next time he comes near us."

"Oh, yes, ma'am. I'll beat him to a mummy. He is chiefly responsible for our pet's illness, I am sure. I'll revenge him without fail."

What a charge, to be sure! Being aware of the great danger to which I was now exposed, I judiciously retraced my steps towards home, without meeting Miss Mikè.

When I came home, I found my master in his study absorbed in reflection, with pen in hand. Had I informed him of the conversation between the two women, how his blood would have boiled! But in blissful ignorance, he was giving himself the air of a Milton. Nevertheless his distracted looks showed that he was not well up in what he was about.

\footnotetext{
* A samurai's attendant.

$\dagger$ A sandal-carrier of a lord or a samurai.
} 
Just then in came Mr. Meitei. His sudden appearance was rather astonishing. It was only three or four days ago that he sent my master the letter containing the season's greetings, in which he remarked that he could not come for the time being as he was very busy.

"Composing a shintai-shi, eh? Let's have a look if you've got a good one."

"No, I found a piece of good prose; so I thought I would translate it," my master opened his lips reluctantly.

"A good piece of prose? By whose pen?"

"I do not know."

"Anonymous, then. We may as well pay due attention to anonymous writings, in which we find not unfrequently some of notable literary value. Where did you get it, pray?"

"From a second reader," answered my master, as calm as calm could be.

"Second reader, did you say? What has become of it?"

"I meant to say that the piece I am translating was found in a second reader."

"No joke, sir. You are going to take me unawares in order to return the compliment for my 'peacocks' tongues.' No, thank you, sir!"

"I am not a brag like you," said my master, twirling his moustache with admirable coolness. 
"An old story is told of San-yô who, when asked by a man if he had recently found an exemplary composition, said, producing a horse-driver's dun for a debt, 'I think this a admirable composition.' Your appreciation may perhaps be as accurate and correct as that of San-yô. Now, read your translation, and I will criticize for you," said Mr. Meitei, with the looks of the greatest authority on esthetics.

"Giant Gravitation," began my master, with a peculiar intone like that of a rector.

"What's that?"

"That's the heading, you know."

"What strange heading! I cannot understand it."

"It signifies a giant with the name of gravitation."

"The significance is rather vague. But never mind. Since it's a heading I will take it for granted. Now, go on to the main subject. It is a treat to me as you have a musical voice."

"None of your blarney." With this preliminary warning, my master went on as follows:-

"Kate looked out of the window. She saw the boys playing ball. They tossed the ball into the air. Up, up it went. Then down it came. They tossed it up again and again. It fell every time. "What makes the ball come down?' said Kate. 'Why doesn't it keep going up?' 'I will tell you,' said Mamma. "A Giant lives down in the earth. He is Giant 
Gravitation. He is very strong. He draws everything toward him. He holds the house down. If he did not, it would fly away. He keeps the children from flying away, too. Did you ever see the leaves falling? Giant Gravitation is calling them. Did you ever drop your books? Giant Gravitation said 'Come.' The ball goes up into the air. Giant Gravitation calls. Then it comes down."

"Is that all?"

"Yes, isn't it fine?"

"Dear! dear! I am utterly defeated. I little thought you would pay me back in my own coin like that."

"Nothing of the sort. I only undertook the translation as I really thought it worth while. You think so, too, don't you?" said my master, looking into the other's face, which shone behind the goldrimmed glasses.

"I am struck with amazement. I never dreamed you were so smart. I confess I am completely taken in this time. So I must haul down my colours," Mr. Meitei wagged his tongue self-complaisantly, leaving my master quite at sea.

"I did not mean in any sense to have the better of you. I simply translated the composition as I thought it capital, and nothing more."

"Yes, it's capital, indeed! You could not have done better. It's marvellous. I am lost in admiration." 
"You need not be so much amazed. You see, I've given up my water-coloring lately, and have got it into my head to be a bit of a writer instead."

"Far better than your painting with neither perspective nor chiaroscuro. It's by far the better plan."

"Your praise is very encouraging." My master was taking the shadow for the substance to the last.

"Good afternoon!" said Mr. Kangetsu, who at that moment came into the room.

"Good afternoon! I've just listened to a wonderful masterpiece of composition, which completely routed the ghost of tochimembo." Mr. Meitei gave utterance to this vague suggestion.

"Oh, is that so? " said the new comer, although not knowing what was meant.

"The other day a man called Ochi Tōfū called on me with your letter of introduction," said my master, who alone retained sedate looks.

"Oh, did he? He is an honest good fellow, this Ochi Kochi, but a little eccentric in his way. So I feared you would find him a bother. But as he insisted upon being introduced to you.......

"Well, no, he was not."

"Did he undertake any explanation with regard to his name?"

"No, I do not remember his doing any of the kind." 
"Didn't he, really? He is used to lecturing on his own name to anyone with whom he is newly acquainted."

"And what does he say? "put in Mr. Meitei, who was looking for something new to occur.

He takes much to heart to hear his name read Tōfū according to Chinese pronunciation."

"You don't say so!" exclaimed Mr. Meitei, taking a pinch of tobacco out of his leather tobaccopouch of golden color.

"He will at once insist that his name is Ochi Kochi, not Ochi Tōfū."

"That's strange, isn't it?" said Mr. Meitei, inhaling deeply the fumes of Kumoi.

"And that entirely comes from his enthusiasm for literature. 'Ochi and Kochi' form the idiom far and near,' besides, they rhyme with each other. This is the point he is proud of. 'They do not appreciate what pains I took with my name,' he will complain, 'when they pronounce it Tōfū by mistake."'

"I see he is really eccentric," rejoined Mr. Meitei, with a look of lively interest. As he said so, he undertook to exhale through his nostrils the smoke he had inhaled. But the smoke had gone down so far that it missed its way, and, sticking in the smoker's throat, caused him to cough violently. 
"When he called on me the other day," said my master, smiling, "he told me that he had played the part of a boatman at the first meeting of the Recitation Society, and made himself the laughingstock of the blue-stockings, who had been watching the proceedings."

"Oh, yes, that's just what I was going to say!" ejaculated Mr. Meitei, tapping his knee with his pipe. Thinking it dangerous to stay near him, I withdrew to a safe distance. "Yes, yes, that Recitation Society! He referred to it when we went to a restaurant for tochimembo. I remember he said that they were going to hold the second meeting on a large scale, inviting a number of eminent men-ofletters, And he cordially requested my attendance. I asked him if he meant to have another drama by Chikamatsu. 'No,' he said, 'we have chosen quite an up-to-date work for our next performance, that is to say, The Konjiki Yasha.' Upon my inquiry of his rôle he said he was to represent Omiya, the heroine. Tôfū playing the part of Omiya! It will be very amusing, I am sure. I must not fail to put in an appearance and cheer him."

"Yes, I have no doubt of its being a sight," said Mr. Kangetsu, with a queer smile.

"But he is true and honest in the perfect sense of the word, not a bit of a humbug. It's a credit to him. He is of quite a different stamp from men like 
Meitei," put in my master, paying off the old scores all at once for Andrea del Sarto, peacocks' tongues, and tochimembo. But Mr. Meitei remained apparently cool and indifferent before this retaliation.

"Yes, you know, I belong to the class of men called Gyôtoku no manaita ${ }^{*}$, returned he, laughing.

"I should say you are something like that, said my master. In reality he was ignorant of the significance of the slang. But as teacher he was long accustomed to covering up his ignorance or fault someway or other. And the use of this art was not merely confined to the class-room, being applied to social transactions as well, whenever occasion required.

"What is meant by Gyôtoku no manaita?" inquired M. Kangetsu frankly.

"The daffodil you see there," broke in my master, casting a hasty glance towards the alcove,

*A play on words, meaning a foolish saucy man. Gyotoku is a fishing village situated on the River Tone, which affords an abundant supply of shell-fish called "baka" (fool) to the people of that place. So their manaita (a board for cutting or cleaning fish ) on are supposed to be much worn on account of the unshelling practice. Hence the expression, "baka de surete oru" (a fool who has become bold by contact with the world). A similar expression, "Fukagawa no handai" is often used. 
"was bought on my way back from a bath-house at the close of last year, and was stuck in the vase by my own hand. Isn't it very durable?" He made a desperate effort to check the course of the conversation concerning the slang.

"Talking of the close of the year, I had a singular experience towards the end of last year," said Mr. Meitei, turning round his pipe on the tip of his nimble fingers like a juggler.

"An experience? Let us hear it!" proposed my master, who drew a long breath, now that he had had the talk on the slang scattered to the wind.

Mr. Meitei's singular experience was to the following effect:-

"To the best of my recollection it was on the twenty-seventh of last December that I received a note from that Tôfū, requesting me to stay at home as he would call upon me in order to hear me talk on literary subjects. So I waited from the morning, expecting his visit at any moment. But he came not. After lunch, I sat before the stove to read a humorous work by Barry Pain. In the course of my reading, a letter came from my mother at Shizuoka. It contained several kind advices. For instance, she urged me not to have night outings during the cold season, and that, if I wanted to take a cold bath at all, I had better take it in a room warmed by a stove lest I should catch cold. 
Poor old mother! She thinks of me as still a boy. Thrice I blessed my parent; for who could be so affectionate and kind? Happy-go-lucky as I am, I was never so much moved as I was then.

Her letter also made me feel ashamed of my idle life, and inspired in me a resolution to turn over a new leaf. I was bound to devote myself to a great literary work, such as might do credit to my house. 'Yes, I must strive,' I said to myself, 'to cut a figure in the literary world of the Meiji Era, while my mother is on this side of the grave.' She further said that I was born under a lucky star to be able to lead a careless indolent life even in the busiest time of the year, as if always in a festive season, while tens of thousands of young men were now, since the outbreak of the war with Russia, fighting hard for this land of Mikado's. But the fact is I am not as idle as my mother thinks. She also added a list of the names of my old schoolmates who were either killed or wounded on the field. When I scanned their names one after the other, a strange sensation of sadness crept over me; I felt weary of the world, and human life seemed a burden. The letter wound up with the sentimental conclusion, 'I am so stricken in years that the cup of next New Year's zoni may prove to be my last one.' I felt the more wretched, and in vain looked every instant for the diversion of a visit from Tōfū. 
Finally supper hour came. After the meal was over, I thought I would write an answer to my mother, and penned some dozen lines. Her letter measured more than six feet; but not being energetic enough to follow her example, I usually excuse myself by sending her an answer consisting of ten lines or so. As you know, I stayed indoors all day, and so from want of exercise I began to feel unwell. 'If Tōfū comes, let him wait till I return,' I said to myself. Thus decided, I went out for a stroll, with my letter to post on the way. Instead of going in the direction to Fujimi-chô as usual, my steps were strangely turned towards Dote-samban-chô for some reason unknown even to myself. It was a cold cloudy evening, with a biting wind blowing direct from over the moat. A train came rushing along from the direction of Kagura-zaka and whistled away below the embankment out of sight. A thrill of loneliness passed through me. Nevertheless, my brain was whirling with varied ideas, such as 'ringing out of the Old Year,' 'death on the battle field,' decrepitude,' 'fatality,' etc.. I had heard of many men who launched into eternity by hanging themselves, and thought they were probably beckoned by Death at such times. I chanced to raise my head, and, to my surprise, found myself right under the identical pine tree." 
"The identical pine-tree? What do you mean?" interrupted my master.

"I mean the "Hang Head Pine-tree," responded Mr. Meitei, shrugging his shoulders.

Why, that is on Kôno-dai, isn't it?" put in Mr. Kangetsu, and widened the circle of the narration.

"The one on Kôna-dai is 'Hang Bell Pine-tree,' and that at Dote- samban-chô, 'Hang Head Pinetree.' And the reason why it came to be known by that name, is, according to an old tradition, that anyone who happens to stand under the tree, is sure to feel like hanging himself. Any case of suicide in the neighboring locality is sure to be found connected with this particular tree, though there are many scores of pine-trees on the bank. In fact, every year sees two or three victims. And it is a curious fact that no one seeks the means of selfdestruction from the other trees. I looked up and saw its arm invitingly spread across the road. Oh, it was of such a complete shape that I thought it a pity to leave it as it was. 'How fine it would be, thought I, "if only there were a man swinging by the neck.' I looked around in the hope that some one might come. As ill luck would have it, there was not a soul to be seen. Under the circumstance, I felt half inclined to try the job myself. The next moment, however, it occurred to me that I should be risking my life by the attempt. This kept me 
from the adventure. But I remembered that the ancient Greeks used to perform a trick of hanging at a feast by way of additional entertainment. One man would stand on a stool and put his neck into a loop of rope. Instantly the stool was kicked out by another. As quick as lightning, the first performer loosened the loop, and down he came on the floor. This was the process of their feat. Admitting this to be an actual truth, I thought there was no reason why I should be afraid to imitate it. For experiment's sake, I caught hold of the branch, which yielded to my weight, and in such an artistic way, too. The thought of swinging buoyantly by the neck sent a thrill of inexplicable delight through me. And I determined to realize the sensation at all hazards. At this critical moment, I accidentally recalled Tōfū, who might be missing me at my house at that moment. I was sorry to keep him waiting; so I thought I might as well put off my experiment until after I had the chat with him as previously arranged. And I ultimately started for home."

"And so ends your story?" asked my master.

"It's very entertaining," said Mr. Kangetsu, grinning.

"When I returned home, I learned that Tōfū had not come, but found a post-card instead, in which he said that on account of an unavoidable 
engagement, he was unable to come to see me that day, but that he would call some day after the beginning of the New Year.

"I drew a breath of relief, for now I could hang myself in peace. With my heart leaping with joy, I instantly put on my wooden clogs and hastened back to the spot with flying feet.......

Here he abruptly stopped and kept glancing at his friends' faces with a singular composure.

"What happened then?" asked my master, with an expression of impatience.

"Ah, your story is becoming exciting," said Mr. Kangetsu, playing with the strings of his haori.

"What did I see?" resumed Mr. Meitei. "A man hanging from the very branch! With the difference of only a step or two, I was forestalled by him. Wasn't it a pity? I think now that I was led there by the hand of Death. Such a man as Prof. James would have said that this was an instance in which something worked in the subconscious world with more than usual activity, causing this peculiar phenomenon to emerge above the margin of consciousness, in which death seemed such a desirable thing, without any apparent cause. At any rate, it was the strangest experience. I ever had," concluded Mr. Meitei, with as calm an air as possible.

My master, thinking he was taken in again, 
remained silent, munching Kuya-mochi with which he had filled his mouth.

Mr. Kangetsu was gingerly smoothing the ashes of the fire-box with the tongs, his head bent down. There lingered the same smirk on his face.

"I dare say your adventure was out of the common run," he said after a while in a very quiet tone, "and would be thought beyond the bounds of possibility by most people. But for my part, I do not for a moment doubt it, since I myself had a similar experience lately."

"And you also felt inclined to hang yourself?"

"No, not hanging in my case; but the thing also happened at the end of last year. What's more, it fell upon the same day and about the same hour as yours. Isn't this a wonderful coincidence?"

"Really it is," answered Mr. Meitei, cramming Kuya-mochi into his mouth after my master's example.

"On that day a Bonen-kwai* and a concert were held at the same time at a friend of mine's who lives at Mukojima. I attended the meeting, carrying my violin with me. It was a rare success; for everything was admirably arranged, and besides the

* Literally a year forgetting meeting; a feast held in order to forget the cares and troubles which occurred in the course of the year. 
company included some fifteen wives and daughters from fashionable society. When the repast as well as the concert was over, we were engaged in a desultory conversation until late at night. I was about to take my leave, when Dr. A's wife approached me and asked in a whisper whether I knew of Miss B's illness. This question struck me, for, when I had seen her two or three days before the meeting, she was in her usual state of health, and not a sign of indisposition about her. I asked the lady for detailed information of her condition. And this is what she told me. Miss B was suddenly attacked with fever on the evening of the day I saw her, and would incessantly talk in delirium. And what was worse, my name would not unfrequently escape her lips."

Not only my master, but Mr. Meitei listened attentively, not venturing to throw in such a trite remark as "Halloo! You are to be envied."

"A doctor was sent for. Medical examination showed that, although he could not specify the disease, her brain was affected by the intense fever. And in case the soporific administered, should not produce the desired effect on her, the case might have a serious turn. The moment I heard this news, I experienced a peculiar thrill of uneasiness. As in a terrible nightmare, I felt weighed down by something heavy as if the very air were 
suddenly turned into solid matter and were hemming me in on all sides. While on the way home, my brain was still distracted with what I had heard, and I felt as if my heart would break. To think that such a beautiful, cheerful, and healthy young lady as Miss B.......

"Excuse my interrupting you; but I remember we have already heard 'Miss B' used twice. If there is no objection, I should like to hear her real name, wouldn't you?" said Mr. Meitei, turning to my master.

"Yes," was the dull reply.

"Allow me, please, to have it untold, as it belongs to a personal affair."

"Ah, you are going to throw us off the scent, then."

"No jesting, if you please, for it is a story of a serious nature. Well, her sudden prostration forcibly reminded me of lovely flowers threatened to be blown by a gust of cruel wind. This thought preyed on my heart, and made me as downcast as if all the life and spirit in me had come to a standstill all at once. With almost staggering steps, I came as far as Azuma Bridge, where I helplessly leaned over the railing and looked down. I could not discern whether the tide was rising or falling. It seemed to me that only a black mass of water was in dull motion. A jinrikisha came running 
from Hanakawadô and rolled past over the bridge. I followed the light of its lantern with my eyes as it grew smaller and smaller, until finally it was lost at the Sapporô Beer Brewery. I turned my eyes upon the water again, when my ear caught the sound of a voice calling me from far up the stream. 'Who could it be,' I thought, 'that is calling my name at this late hour?' In wonder I cast a glance over the dark waters, but could distinguish nothing. Concluding it a delusion, I soon started on my way. I had scarcely taken two steps, however, before I heard the same faint voice calling my name from a distance. I stopped again and listened with attention. When I was called for the third time, I caught hold of the railing for support, my knees smiting each other. That mysterious voice, which seemed to proceed from far, far away, or from the depths of the waters, proved to be no other than that of Miss B's! Yes, it was her voice, sure enough. 'Here I am!' I cried involuntarily by way of response. I was surprised at my own voice; for it came out so loud that the still waters rang with its echo. I looked about me in amazement; there was not a shadow of a man nor a dog, even the moon being hid in a cloud. It was at that moment that an overwhelming desire flashed across my mind to be wrapped in the sable mantle of Night, and carried to where she 
called me. Again her voice pierced my ear in an imploring tone as if calling for my help. 'I shall be with you soon,' I replied this time, and bending over the railing, fixed my eyes upon the black sheet of water, from beneath which the voice appeared to force its way. 'It's beneath the waters,' I thought, and eventually mounted the railing. Here I remained gazing fixedly upon the stream, ready to jump in at the next signal. Soon it floated up in a sad feeble strain. Without a moment's hesitation, I gave a vigorous leap, and a second after went down like a stone."

"So you actually plunged?" exclaimed my master, his eyes bulging in amazement.

"Little did I think you would go so far as that!" observed Mr. Meitei, lightly pinching the tip of his nose.

"After that a stupor came over my senses, followed by complete unconsciousness. When I came to myself I was astonished to find that, though chilly, I was not a bit wet; nor did I feel as if I had taken in water. That I had made a bold plunge admitted of no doubt. With gaping mouth I looked round to find the cause of the mystery. And when I did find it, I could not believe my eyes for a moment. Instead of jumping into the water, I had jumped by mistake upon the middle of the bridge! Imagine how sorry I felt then! 
By the mere mistake of direction I had not gone where the voice came from." Mr. Kangetsu concluded his story with a grin, his fingers as usual fumbling with the strings of his haori.

"Ha! ha! ha!" laughed Mr. Meitei. "It's a very engaging story. And it's a wonder that your experience was of a piece with my own. That, too, would afford good material for Prof. James. It would make an excellent study upon life, elucidating the susceptibility of the human mind. Surely, it would cause a stir in the literary world. By the by, what about Miss B's illness?" he asked inquisitively.

"She seems to be quite well now, for when I made a New Year's call a few days ago, she was in her garden, playing battledoor and shuttlecock with her maid," was the answer.

My master who had hitherto been lost in meditation, now suddenly opened his mouth, not to be beaten by such stories:-

"I have, too."

"You have what?" asked Mr. Meitei, turning up his nose at him.

"I mean some such experience. Mine also occurred at the end of last year."

"How curious that all fell upon the end of last year!" laughed Mr. Kangetsu. A bit of Kuya-mochi was seen sticking to the edge of his broken tooth. 
"And the same hour of the same day, eh?" jeered Mr. Meitei.

"No, the date seems to differ. It was on the twentieth, if I remember correctly. My wife asked me to take her to hear giday ${ }^{*}$ sung by Settsu no Daijô, in lieu of making her oseibô.† I said I would not mind going with her, but that I would first like to know what drama was to be sung that day. 'Unagidani,' said my wife, referring to a paper. 'That's a piece I don't like; let's not go today,' I replied. Thus we gave up the idea of going that day. The next day she came to me again with a paper in her hand, and said I would surely like to hear Hori-kawa, the piece for the day. 'That piece is intended more for its musical accompaniment than for its substance, as a lively performance on the shamisen makes up a greater part of the drama. We won't go,' said I. Thereupon she withdrew with discontented looks. 'Sanjū sangen dô is to-day's performance,' she said to me the following morning; and I am determined to hear it. You may not like this piece, too, but I think you are going to give a treat, not to yourself, but to me, and will be obliging enough to take me along with you,' she pressed me hard. 'If you are so anxious

* A drama set to music.

$\dagger$ A present made at the end of the year. 
to go, I may as well accompany you,' I returned, 'but the announcement that this is his last appearance in Tokyo is daily bringing an overflowing audience. So I bet you they won't admit us if we go unexpectedly. If we want to go to a place where such performances are given, we should first apply to what are called chaya, ${ }^{*}$ and have a seat previously engaged. It is not right to ignore the regular procedure. I am sorry for you; but let us not go to-day.' Then my wife turned upon me a fearful glance and said: 'I am an ignorant woman, and so do not know of such difficult proceedings. But there are Mr. Ohara's mother and Suzuki's Kimiyo-san who gained ready admission without taking any formal steps. Even though you may like regularity as teacher, there is little need for you to go to such trouble. You are so unkind to me!' Her voice was sad and broken. 'Then you shall go with me, though I fear disappointment will await us,' I surrendered. 'Let us go by electric car after supper.' 'No dilly-dallying, dear! We must try to get to the place by four o'clock, if we go at all,' urged my wife with a sudden flow of spirits. Upon my inquiry as to why we must be there by then, she repeated exactly what she had heard

* Waiting-houses belonging to a theatre, which afford conveniences to theatre-goers. 
from Kimiyo-san, saying that unless we get there by four and occupy our seats, we would be unable to find any vacant space. 'Then we can't get in if we go later?' I laid stress upon my question. 'Of course not!' was the reply. Strange to say, it happened at that very instant that a sudden fit of chill was experienced."

"By your wife?" inquired Mr. Kangetsu.

'No, by me.

My wife is always as hearty as can be.

Like a balloon perforated I felt myself shrivelled all at once, and the next moment I was quite helpless with giddiness."

"It was a sudden attack!" put in Mr. Meitei by way of explanation.

"What a mishap! She seldom makes such a request of me, and I wished I could grant it willingly. All the more so, as I have never humored her fancy, subjecting her to pecuniary concerns, and leaving the children all to her care. Fortunately, I had time to spare, and a little pocket money that day. I could have afforded to gratify her wish, and I meant to do so by all means. But what could I do with that chill and giddiness? I could hardly drag myself even to the porch, not to say anything of getting into an electric car. The sorrier I felt for her, the more chilly and giddy I became. Thinking immediate medical attendance would set me all 
right before the appointed time, I consulted with her, and Dr. Amaki was sent for. But the messenger came back with the disappointing reply that he had not yet returned from the hospital, where he had been on duty the night before, but that as he was expected home at about two, he would be told to come to me at once. What a fix I was in! One thing upon another! If I had only taken a little Kyônin-sui* then, I should surely have got well before four. My expectation of enjoying her delighted face-so infrequently seen-was thus likely to be frustrated. 'Is it impossible for you to go?' she asked, with dejected looks. 'No, I will go anyhow,' I replied: 'Keep your mind at ease, as I will try to get well by some means or other by the appointed time. In the meanwhile go and make your toilet, and wait.

Though I said so to keep up her spirits, my heart was in reality swelling high with intense emotions. The cold shudder was growing more violent, while my head whirled with increasing giddiness. If by any chance I should not recover by four to keep my promise, there would be no knowing what she would do, this excitable woman. How could I get out of this embarrassment? A vague dread of unforeseen evil set me

* A medicine made from the pit of the apricot. 
thinking that I had better explain to her, ere it was too late, the vicissitudes of fortune as well as the mortality of the human life. In so doing I might prepare her for the worst, and this was, as I thought, what a man should do for his wife.

I instantly called my wife to my study and asked if she knew the common English proverb which says, 'There is many a slip t'wixt the cup and the lip.' 'How could I?' she retorted brusquely. 'You know I have not even a smattering of English; and you use that tongue on purpose to tease me. Go on and use it as much as you like! I am a poor ignorant woman after all! If you like English so much, why didn't you select your spouse from among graduates of a mission school? I say you are one of the most unfeeling and inconsiderate men I ever saw.' She was so piqued that the wind was entirely taken out of my sails and made me stop short of my intention. I wish to have you understood that my reference to the English proverb originated, not from mischief, but from affectionate regard for my wife. As is to be imagined, it was intolerable to be thus misunderstood by my wife.

The fact is my brain was in a state of disorder from the chill and giddiness, and besides, I was so precipitate in demonstrating to her the important problem aforesaid that I momentarily forgot she was no English scholar, with the result that 
I made mention of the proverb unconsciously. I soon found on reflection that I was careless and the fault was entirely my own. And this feeling made my condition doubly bad.

My wife, as was directed, went to the bathroom, where she busied herself with her toilet, and was soon ready to start at any time. I swallowed a big lump in my throat, and looked for the instant arrival of Dr. Amaki. My watch indicated three,- - only one hour to four! The hinged door opened and my wife peeped in, saying, 'What do you say to setting out presently, though a little early?' Ludicrous as it may sound to admire my own wife, I never saw her appear so lovely as she was then. She was all in a glow with the fresh toilet she had made, contrasting beautifully with her haori of black crape. For two reasons, material and immaterial, her face shone bright - the one, the effect of her soap, the other, the hope of hearing Settsu sing. I had only to make up my mind to go in order to give her satisfaction. 'Let me pluck up my courage and start, then!' I answered, and blazed away at my pipe.

Just then the long-expected doctor came, and in good time, too, as I thought inwardly. When I told him how I came to feel unwell, he examined my tongue, felt my pulse, tapped my breast, rubbed my back, turned my eyelids down, stroked 
my scalp, and was lost in meditation for a time. 'It seems my case is rather serious,' I said. 'No such symptoms,' observed the doctor. 'Can he leave home for a short time?' inquired my wife. 'Well, yes,' and he meditated again. 'Provided he does not feel too ill,' he added shortly. 'I do feel ill,' I put in. 'At any rate, I shall give you both powders and liquid medicine.' 'If you please, sir. I don't know how it is, but I fear I shall have a turn for the worse.' 'No, it's not so serious as that. I advise you not to be nervous.' Saying this the doctor left. It was past half past three.

The maid was immediately sent for the medicines. According to her mistress's strict order, she went and returned at a brisk trot. It was fifteen minutes to four. About this time I was affected all of a sudden with sickly languor. My wife poured the liquid medicine into a cup and placed it before me. I lifted it to my lips, when I felt a sensation of impending nausea, which made me put it down. 'Make haste and drink it,' my wife urged. I thought it wrong to keep her delayed any longer, so I put the cup to my mouth to drink its contents with one determined draught. But I was prevented again by the obstinate qualm. I repeated the same thing again and again, until the clock on the wall of the sitting room struck four. 'It's four! There's not a moment to lose,' I said to 
myself, and again raised the cup. Then it was,wonderful to say! - that the sickly sensation entirely left me, so that I could readily drink the medicine. Ten minutes more, and the reputation of the skilful doctor was amply justified, the cold shudder as well as the giddiness disappearing like a dream. I was delighted at the speedy recovery from an illness which threatened me with confinement for some days."

"And you accompanied her to the Kabuki Theatre?" came from Mr. Meitei who appeared to extract the point of the story.

"No, I wished to; but since we were not likely to obtain admission after four, as was the opinion of my wife, I was obliged to give up the idea. If Dr. Amaki had come fifteen minutes earlier, I could have shown her I was as good as my word on the one hand, and she would have been satisfied on the other. Only a fifteen minutes' difference caused this sacrifice! I still think now that it was really a critical juncture."

My master, thus concluding, assumed an air of having done his duty; he probably thought he could now maintain his dignity towards his companions.

"What a pity, to be sure!" grinned Mr. Kangetsu, showing his broken tooth as usual.

Mr. Meitei, feigning admiration, said as if to 
himself: "Your wife is indeed fortunate to find in you a devoted husband." A forced cough came from my mistress behind the paper-slides.

With quiet patience I listened to each of their stories. But I felt neither merry nor sad. Man is a poor creature at best; he wags his tongue even when he has nothing to say, laughs at what is not amusing, and takes delight in what is not interesting,- - all to kill time. This was my impression. I knew already that my master was selfish and narrow-minded. His customary silence, however, left me in doubt as to his real character. And in this point lay something like fear which I felt toward him. But upon hearing his story this feeling gave place to sudden contempt. Why could he not silently listen to his friends' stories? What benefit could he derive from his gossip by way of competing with them? I wonder if Epictetus would have advised him to act in such a way! In short, my master as well as Kangetsu and Meitei are all idle fellows "idly eating the bread of idleness." Like gourds idly swinging in the wind, they pretend to stand aloof from the world. In reality, however, they are worldly, mercenary, emulous, and unyielding; and these weak characteristics find occasional expression even in their daily conversation and jokes. With but a step they come to a footing with those vulgar people whom they always 
rail in good set terms. They are miserable creatures in the eyes of a cat. If they have one thing to recommend them, it is their freedom from mincing airs of prigs.

Thinking this I suddenly became tired of listening to the conversation between the three men, and was only too glad to turn away from them in order to go and look after Miss Mikè's health. I got round to the musician's garden. Ten days of the New Year had passed; the spring sun was shining high in the azure vault, in which not a cloud drifted, bathing the whole world with his gentle bright rays. And the garden of only about ten tsubo* presented more life and freshness than it did under the first light of the New Year's morning. A cushion lay upon the veranda, but there was not a shadow of an occupant. The paper-slides were all shut; perhaps the music teacher had gone to take a bath. Her absence was of no consequence to me, my sole concern being for Miss Mikè's condition. There was something like desertion about the house, which prompted me to get upon the veranda with my muddy paws. I lay down upon the middle of the cushion, which was so comfortable that doziness came over me, and I soon fell asleep, involuntarily drawing my thoughts from

* One tsubo corresponds to about 36 sq. ft. Eng.. 
Mikè. I was suddenly aroused from my slumber by the voices inside:-

"Thanks for your trouble. Was it ready?"

The music teacher was not absent after all.

"I am sorry I was delayed. Yes, ma'am, I got it from the busshiya, ${ }^{*}$ who said he had it just ready."

"Let me see it. Ah, it's done beautifully. I think this will make Mikè enter Nirvana. The coating of gold does not come off easily?"

"No, ma'am, I asked the maker emphatically about that particular point; and he assured me that, as first-rate gold dust was used, it would be more durable than man's ihai. ${ }^{\dagger}$ He added that the character 誉 in her posthumous name, 猫誉 神名 (the spirit of the Honorable Cat) was conveniently simplified so as to make the whole look well proportioned."

"Well, let me place it upon the altar at once, and burn incense before it."

I wondered what had become of Miss Mikè; something unusual must have taken place in the house. I sprang up upon the cushion, when "ding" was heard the sound of a bell, and the musician's

* A maker of idols and other things used in Buddhist worship.

$\dagger$ A wooden tablet, on which the posthumous name and time of death of a person is inscribed, and worshiped as representing the spirit of the dead. 
voice offering a prayer, "Namu, Myoyo shin-nyo! Namu amida butsu, namu amida butsu."*

"Now, you give mass for her!"

"Ding" rang the bell again, and this time the maid's voice came, "Namu, Myoyo shin-nyo! Namu amida butsu, namu amida butsu."

I felt a sudden throb of my heart, my eyes became fixed, and there I was standing on the cushion, spell-bound like a statue.

"It is indeed regrettable, ma'am! She seemed to have had only a slight attack of cold in the beginning."

"Dr. Amaki should have administered medicine to her."

"Yes, the doctor is to blame after all. He treated her so indifferently,"

"You should not speak so ill of him. Perhaps she had such a destiny."

... seems that Miss Mikè was also attended by Dr. Amaki.

"At all events, I think it is that wicked cat of the teacher's who lives in the front street, that is chiefly accountable for our pet's death. He habitually enticed her out, you know."

"Yes, ma'am, the beast was certainly the cause of her destruction."

* Words used as an invocation in praying to Buddha, meaning, I adore thee, O eternal Buddha. 
I was about to attempt an explanation, but recollecting this was an occasion to be armed with patience, I listened on holding my breath. There was silence for some time.

"It is the way of the world that we cannot have things just as we like. A beautiful cat like Mikè dies an early death, while an ugly mischievous beast like that of the teacher's lives on."

"Exactly as you say! Hunt where you may, you can never find such a lovely cat as our deceased favorite."

"Favorite" instead of a pet! The maid evidently thinks man and the cat are of the same race. And this is not so striking when we look at her whose very appearance resembles our race.

"If it had only been possible that in place of our beloved Mikè......."

"That teacher's nora* had departed this life, all would have ended well and satisfactory."

Not well and satisfactory to me! I have never experienced death, and therefore cannot say how I shall like it. But the other day I sought refuge from the severe cold in a hikeshi-tsubo. ${ }^{\dagger}$ The maid, not knowing I was there, put on the lid, and left me in terrible agony. Even now it makes my blood

* The abbreviation of nora neko (stray cat).

$\dagger$ A pot used for extinguishing live coals. 
run cold when I reflect upon it. According to Mr. White's explanation, it would have been all over with me, if my suffering had lasted a little longer. I would fain have died in place of Miss Mikè. But if death is necessarily accompanied by such awful agonies, I will not die for anyone's sake.

"I believe even the spirit of a cat will not linger, when it has had mass offered by a priest and a posthumous name given."

"Yes, you are quite right, ma'am. The deceased is really to be numbered among the most fortunate. But I only wish, if there were anything to be added, that the priest had not been so sparing in his prayer."

"I also thought it too short. But when I inquired the reason, Rev. Gekkeiji replied that he had read the choice text from the sacred books and that it would be quite sufficient to make a cat enter paradise."

"Did he, really? But such nora......."

I have mentioned more than once that I have no name. Still this maid dared call me "nora." Insolent woman!

"But such nora will not be saved. I am sure, by any divine benediction, as he is an old sinful beast."

I do not know how many times this "nora" was repeated after this, for I turned away from 
their endless chat. When I slipped off the cushion and jumped down from the veranda, I at once erected my eighty-eight thousand eight hundred and eighty hairs and gave myself a hearty shake. I have never since approached the music teacher's house. By this time it is likely that she herself is being offered a sparing prayer by Rev. Gekkeiji.

I am not plucky enough to stir out of late, and feel wearisome of the world. I have become as lazy a stay-at-home as is my master. In fact, I begin to think it reasonable that his habit of keeping in his study can be ascribed to his supposed lost love.

I have as yet caught no rats; and once even a question was brought forth by the maid to turn me out. But my master who knows I am not an ordinary cat would not accept such a proposal. And there I am in his house, still whiling away my time. In this respect I am very grateful to him, and at the same time I do not hesitate to express my admiration for his acumen. I am not much offended at the ill-treatment from the maid who is unable to take in what kind of a cat I am. The day will come when a Hidari Jingorô* would adorn temples and palaces with the carvings of my

* A famous sculptor of the Tokugawa era. He was left-handed. Hence the surname Hidari. 
figure, and a Japanese Steinlen would be glad to picture my features on canvas. Then it is that such a simpleton as the maid will be ashamed of their own shortsightedness. 


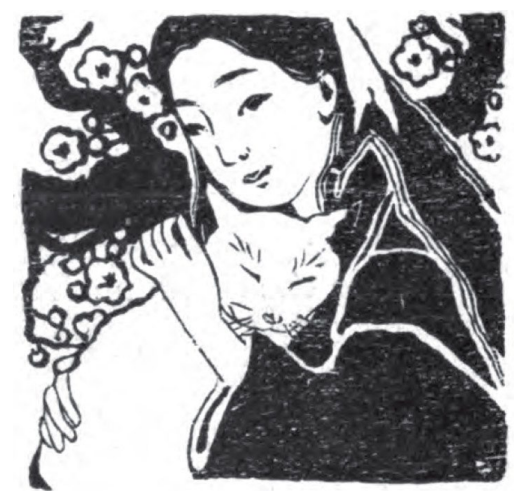




\section{Notes}

Notes at the foot of the page are by the translator, Kan-ichi Ando.

\subsection{Meitei ] 酩酊 drunkenness}

37. the Japan-Russia War] The Russo-Japanese War began in February 1904 with Japanese naval attacks on the Russian fleet at Port Arthur. The last naval engagements ocurred in May 1905, and peace was concluded by the signing of the Treaty of Portsmouth (New Hampshire) in September 1905.

39.20 Kangetsu ] 感 “Feeling, sensation”; 月 “month, moon"

43.11 the fall of Port Arthur ] Russian forces at Port Arthur surrendered January 5, 1905, after being besieged since August 1904. Port Arthur was a naval base in Liaodong Province, Manchuria, that had been leased to Russia by the Qing dynasty of China in 1897.

105.20 killed or wounded on the field. ] Japanese army casualties at Port Arthur were officially listed at nearly 58,000 , though contemporary unofficial estimates ran as high as 90,000 .

109.18-19 Prof. James ] Referring to William James, The Varieties of the Religious Experience (London, 1902).

131.1 Steinlen] Théophile Alexandre Steinlen (1859-1923) was a Swiss-born French Art Nouveau painter and printmaker, known especially for his portraits of cats. 
